\title{
Transparency in Norwegian and Icelandic: Language contact vs. language isolation
}

\section{Marieke Olthof}

This research studies language contact as a possible cause of differences between languages in their degree of transparency. As transparency is assumed to facilitate intelligibility and learnability, especially for adult L2 learners, it is hypothesized that in particular contact settings with many such learners, languages tend to show increasing transparency. The study tests this hypothesis by investigating transparency in Norwegian, which has been exposed to extensive contact with Low German and Danish, and the relatively isolated Icelandic language. Based on a set of opacity features formulated in Functional Discourse Grammar, the degree of transparency of the two languages is compared. The results show that, as predicted, Norwegian is more transparent than Icelandic, which seems due to an increase in transparency in Norwegian and general opacity maintenance in Icelandic compared to their ancestor Old Norse. The study thus supports the hypothesized relation between language contact and transparency.

Keywords: complexity, Functional Discourse Grammar, Icelandic, language contact, learnability, Norwegian, Old Norse, Scandinavian languages, transparency

Marieke Olthof, Amsterdam Center for Language and Communication, University of Amsterdam, Spuistraat 134, 1012 VB Amsterdam,The Netherlands.M.D.Olthof@uva.nl

\section{INTRODUCTION}

The languages of the world are known to differ in their degree of transparency, i.e. in the extent to which they show one-to-one meaning-to-form mappings (Leufkens 2015, Hengeveld \& Leufkens 2017). Thus, whereas some languages display many transparent one-to-one relations, others contain more opaque characteristics. The present study investigates how such differences between languages may be explained, focusing on the influence of language contact. Previous literature on linguistic complexity that has addressed lack of transparency as one of the main components of complexity proposes that extensive but short-term language contact with adult outsiders tends to cause languages to show increasing transparency (Kusters 2003:62; Wray \& Grace 2007:550; Lupyan \& Dale 2010:2; Trudgill 2011:40, 95). Without much contact exposure, by contrast, languages are expected to maintain or even further develop opaque or complex characteristics (McWhorter 2007:4-5; Wray \& Grace 2007:550; Trudgill 2011:64; Leufkens 2015:44). It may thus be hypothesized that languages that have undergone intensive, recurrent contact with foreign adults 
generally show a higher degree of transparency than languages that have developed in a relatively isolated setting.

Important support for this predicted relation between language contact and transparency comes from Leufkens (2013), who demonstrates that creoles, which are young languages that have emerged through large-scale language contact between adults, are indeed more transparent than their sub- and superstrate languages. However, the hypothesis regarding language contact and transparency also predicts that transparency differences can be found between related languages which have developed very similarly genealogically that however have experienced different degrees of language contact. The present study therefore investigates the connection between language contact and transparency by comparing Icelandic and Norwegian (Bokmål) on their degree of transparency.

Icelandic and Norwegian are both descendants of Old Norse, and hence in many ways highly similar, but differ in the degree of contact that they have been exposed to. Whereas Icelandic has been used in a highly isolated setting, Norwegian has over the centuries undergone extensive contact with adult outsiders speaking Low German and Danish (Haugen 1976:64-65; Trudgill 2000:71, 2011:6; Kusters 2003:179). It may therefore be predicted that modern Norwegian shows more transparent features than present-day Icelandic. The common observation that Norwegian has changed considerably from Old Norse, whereas Icelandic has grammatically been relatively stable (Haugen 1976:32; Thráinsson 1994:142; Askedal 2005a:1872; Trudgill 2011:4) supports this prediction, suggesting that Norwegian has acquired more transparent characteristics, whereas Icelandic has been more conservative and still shows opaque features that were already present in Old Norse.

The present study evaluates the degree of transparency of the two languages from a Functional Discourse Grammar perspective (Hengeveld \& Mackenzie 2008). The Functional Discourse Grammar framework, presented in detail in Section 2.1, distinguishes four levels of linguistic organization, i.e. an Interpersonal, Representational, Morphosyntactic and Phonological Level, which describe linguistic utterances in terms of their pragmatic, semantic, morphosyntactic and phonological characteristics respectively. Transparency is then defined as a one-to-one relation between units at each of these levels (Leufkens 2015:13; Hengeveld \& Leufkens 2017). Based on this transparency definition, Leufkens (2015) formulates a set of opacity features which all violate transparency in a different way. Languages that show a large number of these features are considered less transparent than languages that display only few such features. The present paper uses these opacity features to compare the degree of transparency of Norwegian and Icelandic.

The outline of the paper is as follows. Section 2 first describes the definition of transparency and the opacity features proposed in Functional Discourse Grammar, which are used in the present study. Subsequently, Section 3 discusses the notions transparency and complexity and their hypothesized relation to language contact. 
Section 4 then addresses the genealogical relationship between Norwegian and Icelandic and their history as regards their exposure to language contact, showing that these languages can indeed be used to test the hypothesized relation between language contact and transparency. The method used in investigating the degree of transparency of Icelandic and Norwegian is described in Section 5, and Section 6 contains the results of this investigation. Finally, Section 7 discusses the findings and concludes whether the Norwegian and Icelandic data support the hypothesis that languages that have experienced extensive contact with adult outsiders become more transparent than languages that have been more isolated.

\section{TRANSPARENCY IN FUNCTIONAL DISCOURSE GRAMMAR}

\subsection{Defining transparency in Functional Discourse Grammar}

Functional Discourse Grammar (FDG) is a functional linguistic theory that investigates linguistic forms in terms of their communicative functions (Hengeveld \& Mackenzie 2008). The framework makes use of a top-down approach in which language production starts with a communicative intention and ends with the articulation of an utterance. The communicative intention is formed in the pre-grammatical Conceptual Component. This intention is then passed on to the Grammatical Component, which consists of four linguistic levels. The first two levels, the Interpersonal Level (IL) and the Representational Level (RL), take care of the Formulation of the utterance. At the Interpersonal Level the pragmatic units of the utterance, such as illocutions and acts of reference, are accounted for, while the semantic units of the utterance, e.g. propositions and predications, are selected at the Representational Level. Subsequently, Encoding of the utterance takes place at the Morphosyntactic Level (ML) and the Phonological Level (PL), where the utterance is expressed in morphosyntactic and phonological units, such as morphosyntactic and phonological phrases and words. Both Formulation and Encoding may make use of information about the discourse setting and the preceding utterances, kept in the Contextual Component. In this way, the correct use of for instance anaphora and reflexives can be explained. Finally, the utterance proceeds to the Output Component, where it is converted to spoken, signed or written language.

On the basis of the four levels in the Grammatical Component, FDG allows for a very precise definition of transparency (Leufkens 2015:13; Hengeveld \& Leufkens 2017). An utterance is completely transparent if every unit at each level matches exactly one unit at each of the other levels, i.e. when every pragmatic unit corresponds to exactly one semantic unit, which is then encoded as exactly one morphosyntactic and one phonological unit. Figure 1 exemplifies transparent relations between IL and $\mathrm{RL}$ on the basis of the utterance the girl reads. This utterance contains an act of 


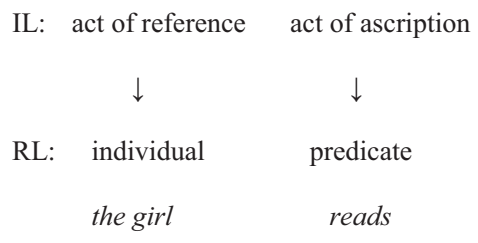

Figure 1. Transparent IL-RL relations.

$\begin{array}{cc}\text { RL: } & \text { plural meaning } \\ \downarrow & \downarrow \\ \text { ML: demonstrative } & \text { inflectional suffix } \\ & \\ \text { these } & -s\end{array}$

Figure 2. A one-to-many RL-ML relation, showing an example of an opaque utterance.

reference, the girl, and an act of ascription, reads, at IL, which transparently match an individual, the girl, and a predicate, reads, at RL.

However, the four grammatical levels distinguished in the Grammatical Component are in principle independent of each other, i.e. there is not necessarily a one-to-one relation between units at IL, RL, ML and PL (Hengeveld \& Mackenzie 2008:16-18). In this way, FDG captures the occurrence of opacity in languages as the lack of an exact one-to-one correspondence between units at any two levels, i.e. at the IL-RL, IL-ML, IL-PL, RL-ML, RL-PL or ML-PL interface (Leufkens 2015:13). For instance, opacity in the form of a one-to-many RL-ML relation occurs in the utterance these houses, in which the semantic plural unit at RL is expressed twice at ML, both by the plural form of the demonstrative and by the plural nominal inflection, as displayed in Figure 2.

By including relations between both pragmatic, semantic, morphosyntactic and phonological characteristics of languages in its definition of transparency, FDG aims to enable one to study the overall degree of transparency of a grammar as a whole, i.e. the degree of global transparency, rather than the degree of local transparency, which would involve studying only one aspect of a grammar, such as its phonology or syntax (compare global vs. local complexity, as discussed by Miestamo 2008:30). The opacity features formulated by Leufkens (2015), to be introduced in Section 2.2, moreover include all mismatches between IL, RL, ML and PL that are recognized in FDG (Leufkens 2015:4), such that all types of grammatical opacity that are possible in the theory are represented. Note however that the FDG approach focuses on grammatical transparency only, i.e. semantic or lexical opacity, such as homonymy, polysemy and non-compositionality in compounds and derivations, is not included (Leufkens 2015:15). 


\begin{tabular}{lll}
\hline Feature & Definition & Example \\
\hline Clausal agreement & $\begin{array}{l}\text { RL-ML: semantic property of } \\
\text { an argument (e.g. number, } \\
\text { person, etc.) copied to the } \\
\text { predicate }\end{array}$ & $\begin{array}{l}\text { English, he walks: person and } \\
\text { number expressed both by the } \\
\text { pronoun argument } h \text { and the }-s \\
\text { suffix on the predicate }\end{array}$ \\
\hline Phrasal agreement & $\begin{array}{l}\text { RL-ML: semantic property of } \\
\text { a head noun, e.g. number, } \\
\text { gender, etc., copied to one or } \\
\text { more of its modifiers }\end{array}$ & $\begin{array}{l}\text { English, these houses: number } \\
\text { expressed both by the suffix }-s \\
\text { on the head noun and the form } \\
\text { of the demonstrative modifier } \\
\text { these }\end{array}$ \\
\hline Tense copying & $\begin{array}{l}\text { RL-ML: tense operator of a } \\
\text { main clause copied to its } \\
\text { embedded clause, leading to } \\
\text { redundant marking of main } \\
\text { clause tense }\end{array}$ & $\begin{array}{l}\text { English, } \text { I saw that she fell } \\
\text { down: past tense of the main } \\
\text { clause expressed both by the } \\
\text { main clause verb and the } \\
\text { embedded clause verb }\end{array}$ \\
\hline
\end{tabular}

Table 1. Redundancy features in FDG (Leufkens 2015) investigated in the present study.

\subsection{Opacity features}

Opacity thus obtains when the one-to-one relation between units at different grammatical levels is violated. Several types of transparency violations can be identified, and each type can take the form of various opacity features (Leufkens 2015). In this section these opacity features are briefly defined and exemplified. More extensive exemplification follows in Section 6, which studies the manifestation of the features in Norwegian and Icelandic.

The first type of transparency violations is redundancy, which involves one unit of meaning corresponding to more than one unit of form, i.e. a one-to-many relation between two levels (Leufkens 2015:18). In general, redundancy obtains when one semantic unit is copied onto another element such that it is formally represented more than once. The present study investigates all redundancy features formulated in FDG, except for the features that Leufkens $(2015: 50-63,137)$ assumes to be (almost) universal or practically immeasurable and thus seem unsuitable for a comparison of languages' degree of transparency. ${ }^{1}$ The investigated features are shown in Table 1.

Secondly, non-transparency may take the form of discontinuity (Leufkens 2015:19). In this case, two units that belong together at one level are separated from each other at another level, leading to a one-to-fragments relation. Table 2 presents the four discontinuity features distinguished in FDG.

A third type of opacity, called fusion, involves a many-to-one relation between levels, i.e. one formal element expresses more than one meaning (Leufkens 2015:19). Table 3 presents the fusion features recognized in FDG. 


\begin{tabular}{|c|c|c|}
\hline Feature & Definition & Example \\
\hline Extraposition/extraction & $\begin{array}{l}\text { RL-ML: head and } \\
\text { modifiers belonging } \\
\text { together semantically } \\
\text { expressed } \\
\text { non-adjacently }\end{array}$ & $\begin{array}{l}\text { English, We have several } \\
\text { important books in store about } \\
\text { global warming (Van de Velde } \\
\text { 2012:433): modifier about } \\
\text { global warming non-adjacent } \\
\text { to the head books }\end{array}$ \\
\hline Raising & $\begin{array}{l}\text { RL-ML: argument } \\
\text { semantically belonging } \\
\text { to the embedded clause } \\
\text { expressed as argument } \\
\text { of the main clause }\end{array}$ & $\begin{array}{l}\text { English, The horses seem to } \\
\text { be ill (Leufkens 2015:66): } \\
\text { semantic argument of the } \\
\text { embedded verb the horses } \\
\text { expressed as argument of the } \\
\text { main clause }\end{array}$ \\
\hline Circumfixes/infixes & $\begin{array}{l}\text { RL-ML: one semantic } \\
\text { unit expressed as an affix } \\
\text { or adposition that either } \\
\text { consists of two parts or } \\
\text { separates another unit by } \\
\text { appearing inside it }\end{array}$ & $\begin{array}{l}\text { French, ne . . pas (Leufkens } \\
\text { 2015:66): negation expressed } \\
\text { as two separated parts } \\
\text { (circumposition) }\end{array}$ \\
\hline Non-parallel alignment ${ }^{a}$ & $\begin{array}{l}\text { ML-PL: } \\
\text { morphosyntactic units } \\
\text { not directly matching } \\
\text { phonological units }\end{array}$ & $\begin{array}{l}\text { English, mustn't (Aikhenvald } \\
\text { 2007:2): two morphosyntactic } \\
\text { words must and not expressed } \\
\text { as a single phonological word }\end{array}$ \\
\hline
\end{tabular}

${ }^{\text {a }}$ Leufkens (2015) does not include this feature in her typological study as it is generally not measurable on the basis of reference grammars. However, as enough data were available for Norwegian and Icelandic, this feature is nevertheless included in the present study.

Table 2. Discontinuity features in FDG (Leufkens 2015).

Fourthly, opacity may be due to a null-to-one relation between two levels (Leufkens 2015:17-18). This type of non-transparency is called form-based form, as it typically involves the presence of a morphosyntactic or phonological unit that does not correspond to any pragmatic or semantic unit, such that a particular grammatical form or distinction is only formally required. Table 4 shows the FDG form-based form features.

A final logically possible violation of the one-to-one principle involves oneto-null relations, in which a unit of meaning is present without being encoded at the Morphosyntactic or Phonological Level (Leufkens 2015:17). Although this type of relation is certainly non-transparent, it cannot be used to diagnose opacity in languages, as it is not possible to prove the presence of a pragmatic or semantic unit without any formal evidence for it (Leufkens 2015:17). For instance, some models assume the existence of non-overt arguments, but it always remains uncertain 


\begin{tabular}{|c|c|c|}
\hline Feature & Definition & Example \\
\hline Cumulation & $\begin{array}{l}\text { RL-ML: case + another } \\
\text { semantic category (e.g. } \\
\text { number, gender) or } \\
\text { tense/aspect/mood/evidentiality } \\
\text { (TAME) + another semantic } \\
\text { category (e.g. person, number) } \\
\text { expressed in a single form }\end{array}$ & $\begin{array}{l}\text { Latin, nominal suffixes - } a \text {, } \\
-u s \text {, etc.: case and number } \\
\text { expressed in a single } \\
\text { morpheme }\end{array}$ \\
\hline Suppletion & $\begin{array}{l}\text { RL-ML: both a lexical } \\
\text { meaning and a grammatical } \\
\text { meaning expressed by a } \\
\text { suppletive stem }\end{array}$ & $\begin{array}{l}\text { English, went: lexical } \\
\text { meaning 'go' and past } \\
\text { tense expressed in a single } \\
\text { morpheme }\end{array}$ \\
\hline Irregular stem formation & $\begin{array}{l}\text { RL-ML: both a lexical } \\
\text { meaning and a grammatical } \\
\text { meaning expressed by an } \\
\text { irregular stem }\end{array}$ & $\begin{array}{l}\text { English, women: lexical } \\
\text { meaning 'woman' and } \\
\text { plurality expressed in a } \\
\text { single morpheme }\end{array}$ \\
\hline
\end{tabular}

Table 3. Fusion features in FDG (Leufkens 2015).

whether a clause contains a non-overt argument or whether its verb uses an alternative argument structure with one less argument. One-to-null relations are therefore not included in the set of opacity features.

Note that the FDG types of opacity described in this section partly overlap with the non-transparency classifications by Kusters (2003:26-30) and Miestamo (2008:34-36), who recognize syntagmatic and paradigmatic one-to-many and manyto-one meaning-to-form relations as violations of transparency. Syntagmatic one-tomany relations, syntagmatic many-to-one relations, and paradigmatic one-to-many relations correspond to redundancy and discontinuity, fusion, and form-based form respectively. However, paradigmatic many-to-one relations are excluded from the FDG approach as they, in contrast to the other types of opacity discussed, often relate to the lexicon rather than to the grammar, while the FDG approach concerns grammatical rather than lexical transparency (Leufkens 2015:15, 31).

\subsection{Varying degrees of transparency}

The opacity features described in Section 2.2 can be used to determine the degree of transparency of a language by evaluating for each feature whether or not it is present in the language under consideration (see Section 5 for a discussion of this method). On the basis of a typological study Leufkens (2015) shows that languages vary greatly in the number of opacity features that they show and thus in their degree of transparency. However, Leufkens (2015:127) also demonstrates that this variation 


\begin{tabular}{|c|c|c|}
\hline Feature & Definition & Example \\
\hline Grammatical gender & $\begin{array}{l}\text { RL-ML: agreement forms } \\
\text { in the noun (or verb) phrase } \\
\text { dependent on gender that } \\
\text { has no semantic basis }\end{array}$ & $\begin{array}{l}\text { German, der, die, das: nouns } \\
\text { combined with formally } \\
\text { different articles on a } \\
\text { non-semantic basis }\end{array}$ \\
\hline Nominal expletives & $\begin{array}{l}\text { RL-ML: formal expression } \\
\text { of an argument that has no } \\
\text { semantic counterpart }\end{array}$ & $\begin{array}{l}\text { English, it is raining: } \\
\text { grammatical subject it not } \\
\text { referring to a semantic unit }\end{array}$ \\
\hline Syntactic functions & $\begin{array}{l}\text { IL/RL-ML: marking of } \\
\text { arguments dependent on } \\
\text { syntactic rather than } \\
\text { pragmatic or semantic } \\
\text { characteristics }\end{array}$ & $\begin{array}{l}\text { English, he works, he sleeps: } \\
\text { form of pronominal subjects } \\
\text { of intransitive verbs } \\
\text { independent of } \\
\text { semantic/pragmatic functions }\end{array}$ \\
\hline $\begin{array}{l}\text { Complexity determines } \\
\text { constituent order }\end{array}$ & $\begin{array}{l}\text { IL/RL-ML: position of } \\
\text { constituents dependent on } \\
\text { their morphosyntactic } \\
\text { weight (e.g. noun phrases } \\
\text { with many complex } \\
\text { modifiers have another } \\
\text { position than short, simple } \\
\text { noun phrases) and not on } \\
\text { their pragmatic or semantic } \\
\text { characteristics }\end{array}$ & $\begin{array}{l}\text { English, he lifted up the books } \\
\text { vs. *he lifted up it: position } \\
\text { dependent on weight of object } \\
\text { noun phrase }\end{array}$ \\
\hline $\begin{array}{l}\text { Predominant } \\
\text { head-marking }\end{array}$ & $\begin{array}{l}\text { RL-ML: marking of a } \\
\text { semantic unit as an affix on } \\
\text { the head and as such } \\
\text { formally dependent on this } \\
\text { head, and not as } \\
\text { independent, formally } \\
\text { invariable clitic or particle }\end{array}$ & $\begin{array}{l}\text { Latin, nominal suffixes }-a,-u s \text {, } \\
\text { etc.: form of suffixes } \\
\text { dependent on a head noun } \\
\text { they attach to, in contrast to, } \\
\text { for instance, formally } \\
\text { invariable adpositions } \\
\text { combining with a noun phrase }\end{array}$ \\
\hline $\begin{array}{l}\text { Morphophonologically } \\
\text { conditioned stem } \\
\text { alternation }\end{array}$ & $\begin{array}{l}\text { RL-PL: phonological form } \\
\text { of a stem dependent on the } \\
\text { form of an adjacent } \\
\text { morpheme and not on } \\
\text { semantic characteristics }\end{array}$ & $\begin{array}{l}\text { English, break - broken: stem } \\
\text { break changed into brok- } \\
\text { when the suffix -en is added }\end{array}$ \\
\hline $\begin{array}{l}\text { Morphologically } \\
\text { conditioned affix } \\
\text { alternation } \\
\text { (conjugation/declension) }\end{array}$ & $\begin{array}{l}\text { RL-PL: phonological form } \\
\text { of an affix dependent on the } \\
\text { morphological category of } \\
\text { the stem it attaches to and } \\
\text { not on semantic } \\
\text { characteristics }\end{array}$ & $\begin{array}{l}\text { Latin, nominal suffixes }-a,-u s \text {, } \\
\text { etc.: form depending on } \\
\text { declension class of the noun }\end{array}$ \\
\hline
\end{tabular}

Table 4. Form-based form features in FDG (Leufkens 2015). 


\begin{tabular}{|c|c|c|}
\hline Feature & Definition & Example \\
\hline $\begin{array}{l}\text { Morphophonologically } \\
\text { conditioned affix } \\
\text { alternation }\end{array}$ & $\begin{array}{l}\text { RL-PL: phonological form } \\
\text { of an affix dependent on the } \\
\text { morphophonological } \\
\text { characteristics of the stem } \\
\text { it attaches to and not on } \\
\text { semantic characteristics }\end{array}$ & $\begin{array}{l}\text { Dutch, plural suffix -en or }-s \\
\text { (Leufkens 2015:91): form } \\
\text { dependent on whether the } \\
\text { stem is stressed or not }\end{array}$ \\
\hline $\begin{array}{l}\text { Phonologically } \\
\text { conditioned stem } \\
\text { alternation }\end{array}$ & $\begin{array}{l}\text { RL-PL: phonological form } \\
\text { of a stem dependent on the } \\
\text { phonological } \\
\text { characteristics of an } \\
\text { (almost) adjacent phoneme } \\
\text { and not on semantic } \\
\text { characteristics }\end{array}$ & $\begin{array}{l}\text { English, ten - tenth (Giegerich } \\
\text { 1992:29): stem-final /n/ } \\
\text { pronounced dentally under } \\
\text { influence of adjacent dental } \\
\text { stop /t/ }\end{array}$ \\
\hline $\begin{array}{l}\text { Phonologically } \\
\text { conditioned affix } \\
\text { alternation }\end{array}$ & $\begin{array}{l}\text { RL-PL: phonological form } \\
\text { of an affix dependent on the } \\
\text { phonological } \\
\text { characteristics of an } \\
\text { (almost) adjacent phoneme } \\
\text { and not on semantic } \\
\text { characteristics }\end{array}$ & $\begin{array}{l}\text { Dutch, past tense suffix -te or } \\
\text {-de (Leufkens 2015:94): form } \\
\text { dependent on voice of final } \\
\text { consonant of the stem }\end{array}$ \\
\hline
\end{tabular}

\footnotetext{
${ }^{a}$ Note that the term head-marking here concerns marking of semantic units on the head of a phrase in contrast to marking on the phrase as a whole. This opacity feature thus concerns a distinction between head- and phrase-marking and does not deal with the distinction between head- and dependent-marking as discussed by Nichols (1986).
}

Table 4. Continued.

between languages is not random but can instead be described by an implicational hierarchy, represented in Figure $3 .^{2}$ This hierarchy is implicational in that features higher on the hierarchy are predicted to occur in languages only if they also show all features lower on the hierarchy. In Leufkens' study of 22 languages only one counterexample to this hierarchy is attested: Samoan shows irregular stem formation without displaying predominant head-marking, although the latter feature is ranked lower (Leufkens 2015:131).

Not all features discussed in Section 2.2 appear in the hierarchy in Figure 3, as the distribution of some features does not seem to show a cross-linguistic pattern. Interestingly, all discontinuity features are absent from the hierarchy, as the presence of discontinuity does not appear to be related to the overall degree of transparency of a language (Leufkens 2015:136). For the other types of opacity, Leufkens (2015:132, 140-141) notes that those features that involve a high degree of syntacticity, i.e. syntactic structure that does not reflect semantic or pragmatic motivations, appear 
nominal expletives, clausal agreement

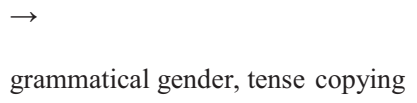

a The term redundant referential marking comprises the opacity features clausal agreement and crossreference, which is similar to clausal agreement except that the argument may be optionally be omitted (Leufkens 2015:122). Cross-reference is not relevant for Norwegian and Icelandic as these languages show clausal agreement, in which the argument is obligatorily expressed.

Figure 3. Implicational hierarchy of opacity features (Leufkens 2015:127).

least frequently in languages. By contrast, features involving phonology tend to occur low on the hierarchy (Leufkens 2015:141), and phonological transparency thus seems to be violated relatively easily.

\section{COMPLEXITY, TRANSPARENCY AND LANGUAGE CONTACT}

The investigation of transparency is closely intertwined with the study of linguistic complexity, which has been the topic of an increasing body of literature (e.g. Kusters 2003, Dahl 2004, McWhorter 2007, Miestamo, Sinnemäki \& Karlsson 2008, Sampson, Gil \& Trudgill 2009, Kortmann \& Szmrecsanyi 2012, Newmeyer \& Preston 2014). While defining and measuring complexity can be problematic (McWhorter 2001:133; Miestamo 2008:30), many scholars assume that one central characteristic 
of complexity is a low degree of transparency, that is, a low proportion of one-to-one meaning-to-form correspondences in linguistic structures (Kusters 2003; Miestamo 2008; Sinnemäki 2008, 2009; Trudgill 2011), and the present research follows this assumption. Complexity may both be regarded as an absolute notion, i.e. as an objective concept that captures the complexity of a grammatical system, and as a relative notion, i.e. as the difficulty of a language for particular language users as regards acquisition and processing (Dahl 2004:39; Miestamo 2008:24). Relative complexity, i.e. difficulty, is often defined with reference to adult second language (L2) learners (Kusters 2003; Szmrecsanyi \& Kortmann 2009:65; Trudgill 2011). Transparency, being a component of complexity, may also be investigated both from an absolute and from a relative perspective. On the one hand, transparency can be measured objectively (Dahl 2004, McWhorter 2007, Miestamo 2008), and the FDG opacity features discussed in Section 2.2 allow for such a measurement. On the other hand, transparency has been considered a part of relative complexity in terms of difficulty for adult L2 learners, as a low degree of transparency has been argued to make languages more difficult for them to acquire (Kusters 2003:55-56; Sinnemäki 2009:128; Housen \& Simoens 2016:168), while increasing transparency has been proposed to make a language easier for such learners (Wray \& Grace 2007:551; Trudgill 2011:41).

Languages have been shown to differ in their degree of transparency, and one may wonder how such differences arise. One of the possibly relevant factors with respect to this issue is language contact, which has also been investigated as a cause of complexity in general by for instance McWhorter (2001), Kusters (2003), Sinnemäki (2009), Szmrecsanyi \& Kortmann (2009) and Trudgill (2011). Since transparency has been argued to facilitate adult L2 learning, in contact settings with many adult L2 learners transparency may be preferred. More specifically, Kusters (2003:62), McWhorter (2007:4-5), Wray \& Grace (2007:557), Trudgill (2011:40-41) and Maitz \& Németh (2014:3) hypothesize that in settings with extensive language contact with large numbers of adult L2 learners that are generally only in contact with L1 speakers during a short time in which the L1 speakers and L2 learners simply focus on understanding each other rather than on perfect learning, simplification in the form of increasing transparency tends to take place, especially when there is no strict adherence to norms in the language involved (Maitz \& Németh 2014:21-22). By contrast, languages that have not experienced much contact are expected to retain or even increase their degree of complexity, including opacity (McWhorter 2007:4-5; Wray \& Grace 2007:550; Trudgill 2011:64; Leufkens 2015:44). Of course, languages in the relevant contact settings do not necessarily become fully transparent. For instance, highly complex, irregular forms may remain complex due to their high token frequency, which also facilitates L2 learning (Ellis \& Schmidt 1997). Nevertheless, the expectation is that these languages overall show increasing transparency. The most extreme examples of such settings can give rise to creoles (Trudgill 2001), which 


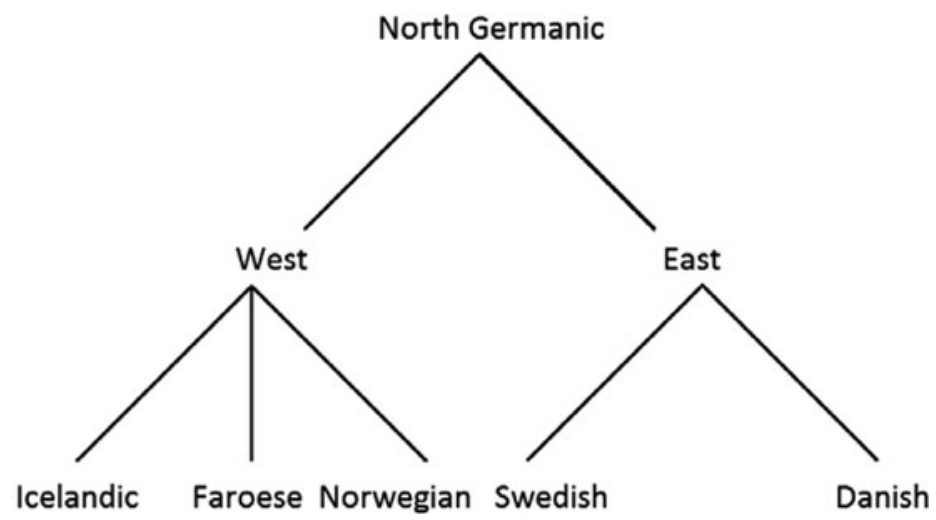

Figure 4. The North Germanic languages, divided into a West and an East Scandinavian group (based on Torp 2004:30).

have been argued to consistently display a high degree of simplicity (McWhorter 2001) or, more specifically, transparency (Leufkens 2013).

Importantly, although dialect contact, i.e. contact between genealogically closely related and typically mutually intelligible languages, and contact between non-related languages may generally have very different results, simplification and increasing transparency may occur in contexts with either type of contact (Jahr 1999:131; Duke 2010:649-650; Trudgill 2011:68). Note, however, that the type of contact setting seems decisive, as language contact may also lead to complexification, including an increase in opacity. This type of language change is predicted to occur in stable, long-term contact settings with a high degree of bilingualism and many child learners (Trudgill 2011:34).

\section{ICELANDIC AND NORWEGIAN AND LANGUAGE CONTACT}

\subsection{The North Germanic languages}

Icelandic and Norwegian belong to the Northern branch of the Germanic languages, which are part of the Indo-European family (Vikør 2001:32; Torp 2004:25). The North Germanic languages can be further divided into a West and an East Scandinavian group, which emerged in the seventh century, when the dialects spoken in Scandinavia split into two as a consequence of a number of sound changes (Faarlund 1994:38; Vikør 2001:33, 37-38; Torp 2004:30, 56). These groups are shown in Figure 4. The West Scandinavian language or dialect group is usually called Old Norse and was spoken in Norway (Faarlund 1994:38; Vikør 2001:37). As the first settlers of Iceland and the Faroe Islands, who arrived around the year 900, came from Norway, the Old Norse language also reached these countries (Vikør 2001:57, 61). 


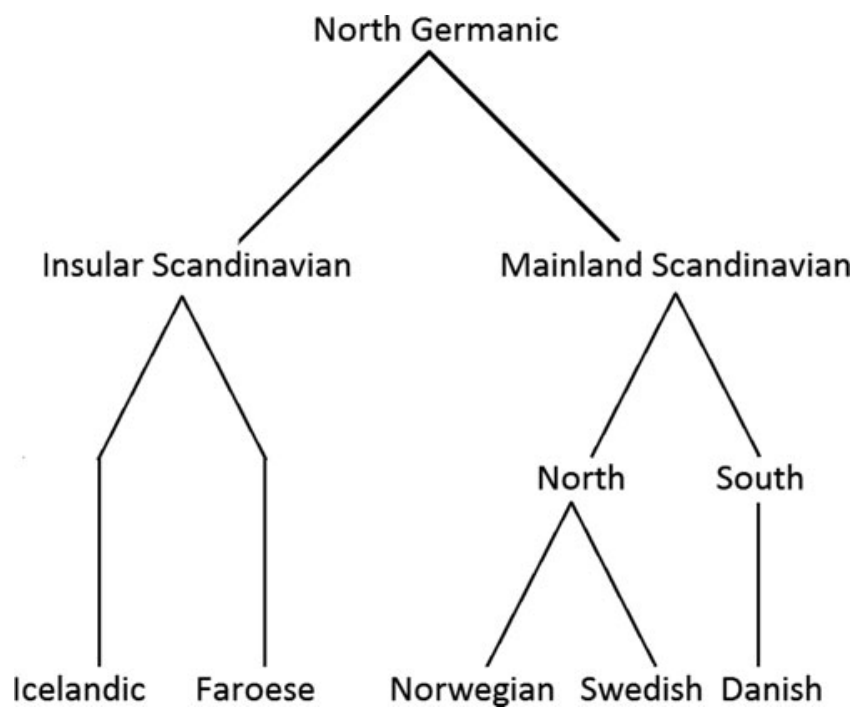

Figure 5. The North Germanic languages, divided into Insular Scandinavian and Mainland Scandinavian (based on Torp 2004:45).

Modern Norwegian and modern Icelandic both descended from Old Norse and are thus very closely related (Torp 2004:30). Nevertheless, present-day Norwegian seems much more similar to Swedish and Danish, i.e. the East Scandinavian languages, than to Icelandic (Torp 2004:30; Husby 2007:8). On the basis of the current status of the Scandinavian languages it is therefore more useful to divide them into Insular Scandinavian (Icelandic, Faroese) and Mainland Scandinavian (Norwegian, Danish and Swedish) (Vikør 2001:45; Torp 2004:45), as in Figure 5.

\subsection{Language contact in Norwegian}

Over the centuries, the Norwegian language has clearly been affected by language contact (Haugen 1976:64-65; Kusters 2003:191; Jahr 2008:247). In the first place, during the late Middle Ages, intensive trade with the Hansa League led to language contact with Low German (Haugen 1976:65; Vikør 2001:42; Kusters 2003:192). Large numbers of German adult men came to Norway, who typically did not settle permanently but rather stayed for a short period, without becoming fluent in Norwegian (Trudgill 2000:75, 2011:57; Kusters 2003:192; Jahr 2008:250). Learning Norwegian was not necessary, as the Germans and Norwegians only needed to communicate in order to facilitate trade and their languages were probably to a considerable extent mutually intelligible (Skard 1976:132; Braunmüller 1997:367; Kusters 2003:192; Mæhlum 2005:1910; Jahr 2008:250; Trudgill 2011:25). Moreover, Low German was considered a highly prestigious language, and as variation was normal due to the lack of a linguistic standard, Norwegians were relatively willing 
to adapt to Low German (Braunmüller 1997:371-372; Vikør 2001:42; Kusters 2003:192-193; Mæhlum 2005:1910).

This contact with Low German has been argued to have had a great impact on the Norwegian language. Not only were large numbers of words and derivational affixes borrowed from Low German into Norwegian (Vikør 2001:42-43; Mæhlum 2005:1910; Jahr 2008:246), but it has also been suggested that this contact has been a major factor in the simplification that much of the Norwegian inflection has undergone since the Old Norse period (Haugen 1976:65; Vikør 2001:44; Kusters 2003). The language contact with Low German also seems to be the primary reason that classifications of the North Germanic languages focusing on synchronic similarity and mutual intelligibility distinguish Insular and Mainland rather than West and East Scandinavian, as Low German has greatly affected Swedish, Danish and Norwegian whereas it has only marginally influenced Icelandic and Faroese (Vikør 2001:42-44, 2010:12; Kusters 2003:181).

Secondly, Norwegian has experienced extensive language contact with the Danish language, which has also been claimed to have played a role in the observed inflectional simplification in Norwegian (Kusters 2003). In the 14th century Norway became included in a union state with Denmark and Sweden, and while Sweden left the union in 1523, Norway continued to be part of the Danish kingdom until 1814 (Vikør 2001:25; Otnes \& Aamotsbakken 2012:69-70). From the beginning Norway was the weakest part of the union state, which was at least partly due to the disastrous effects of the Black Death in 1349-1350, which reduced the Norwegian population by at least fifty per cent and had a greater impact in Norway than in the other Scandinavian countries (Vikør 2001:25; Kusters 2003:194; Mæhlum 2005:1910; Husby 2007:8; Otnes \& Aamotsbakken 2012:68). ${ }^{3}$ Most of the Norwegian nobility and clergy died during the plague and became replaced by Danes (Skard 1972:15, 1976:128-129; Sandøy 1981:37; Otnes \& Aamotsbakken 2012:68). Importantly, as these high class Norwegians had been the only ones able to write, with their death the Norwegian written language also disappeared (Sandøy 1981:37; Torp \& Vikør 1994:117; Kusters 2003:194; Husby 2007:8). During the Reformation in 1536 Danish replaced Latin as the language of the church, and soon Danish bishops and priests were recruited and a Danish Bible translation, published in 1550, came in use (Skard 1972:13-14; Vinje 1978:15, 27; Otnes \& Aamotsbakken 2012:97). At the same time, the Norwegian council (Riksrådet), which soon after the Black Death already had many Danish members, was abolished (Skard 1972:12; Torp \& Vikør 1994:117; Mæhlum 2005:1914; Otnes \& Aamotsbakken 2012:70, 96), and Norway officially became a province of Denmark, with Danish as the only language of administration (Skard 1972:15; Roksvold 1981:46, 48; Otnes \& Aamotsbakken 2012:96). Through the Danish church services, catechesis in Danish, and schooling, which became obligatory in 1739, in Danish, the Danish language also reached the common people (Skard 1972:13, 61; Roksvold 1981:51; Mæhlum 2005:1914-1915). 
The contact with Danish does not seem to have led to widespread bilingualism, but rather to Norwegians adapting their language use (Vinje 1978:27; Mæhlum 2005:1913-1914; Otnes \& Aamotsbakken 2012:106). This accommodation was probably easily possible because Norwegian and Danish were highly similar, such that Norwegians and Danish could typically understand each other (Vikør 2001:5960; Mæhlum 2005:1913-1914). Only after 1775 did Danish become a subject in school (Otnes \& Aamotsbakken 2012:113). Moreover, Danish became a prestige language, such that people copied Danish elements, and especially urban and high class Norwegians used a Danish-like Norwegian, based primarily on written Danish (Roksvold 1981:48, 52; Torp \& Vikør 1994:118; Vikør 2001:54). The influence of Danish on Norwegian was further facilitated by the dialect variation and lack of prescriptive linguistic norms in Norway in general, which made the Norwegian language relatively flexible (Skard 1972:32; Torp \& Vikør 1994:116). Furthermore, until around 1800 the Danish written form was not fixed either (Roksvold 1981:51; Otnes \& Aamotsbakken 2012:119), such that mixing of Norwegian and Danish elements in writing was also easily possible (Vinje 1978:40; Torp \& Vikør 1994:117).

The influence of Danish is still clearly visible today. In the 19th century, when the union with Denmark had been dissolved, two separate written forms of Norwegian developed (Bull 2005:1468-1473; Husby 2007:9; Vikør 2010:2023). Whereas Bokmål was formed on the basis of Danish and urban language use by gradually replacing Danish characteristics by Norwegian ones, Nynorsk was based on Norwegian rural dialects. Consequently, especially in Bokmål and the spoken variants closely resembling it, which are the most widely used and the most prestigious (Vikør 2001:57; Kusters 2003:195; Mæhlum 2005:1921), influence from Danish can be found. Moreover, present-day Norwegian is still characterized by a widespread use of dialects and relatively low linguistic normativity (Vikør 2001:211212; Kusters 2003:195; Mæhlum 2005:1912; Husby 2007:9), which may at least partly be due to the long-term Danish supremacy and the consequent late development of Norwegian standardized forms (Vikør 2001:211). Modern Norwegian also shows clear examples of change through dialect contact (Vikør 2001:212). For instance, in several Norwegian towns that experienced extensive immigration from other parts of the country in the last century koine dialects developed, which typically show simplification (Røyneland 2003:57-58).

\subsection{Language contact in Icelandic}

Icelandic is usually argued to be the most conservative Scandinavian language and especially its morphology and syntax have changed relatively little over the centuries (Haugen 1976:32; Thráinsson 1994:142; Torp 2004:59). Probably one of the primary reasons for this conservatism is the isolated development of the language (Haugen 1976:32-33; Sandøy 2004:61). First of all, Iceland's location has naturally led to 
isolation (Kusters 2003:182). Consequently, the country was for instance never really integrated in the Hansa network (Vikør 2010:12). Even though some Low German words have entered the Icelandic language, the contact with this language was relatively limited.

Secondly, although Iceland became part of the Danish kingdom around 1400, just like Norway, contact with the Danish language was never very extensive (Kusters 2003:183). Despite the Danish supremacy, the Icelanders were relatively free to use their own language (Vikør 2001:59). The Icelandic written language, which had been used for several centuries and in which the well-known saga literature was written, remained in use (Vikør 2001:59). In 1584 an Icelandic Bible translation was published and Icelandic became the language of the church (Vikør 2001:59). Another important factor was that Icelandic differed much more from Danish than Norwegian did. Thus, the Icelanders did not adapt to Danish as easily as the Norwegians (Vikør 2001:59-60).

The lack of contact-induced language change has also been related to the fact that Icelandic has always been a remarkably uniform language with relatively few dialectal differences (Thráinsson 1994:142; Karlsson 2004:64; Leonard 2011:169). Proposed reasons for this situation are the relatively homogeneous language of the first settlers (Leonard 2011:175), the pattern of settlement of the people on isolated farms (Sandøy 2004:61), and the widespread literary tradition (Haugen 1976:33; Karlsson 2004:64; Leonard 2011:179). Icelandic has thus always been a unified language, which may have helped the language to resist external influences.

Finally, with respect to the present-day language climate in Iceland it may be noted that there is an active and widely supported policy of language purism (Karlsson 2004:66; Vikør 2010:23). Thus, even today influence from other languages is relatively limited.

\section{METHOD}

On the basis of the hypothesis concerning language contact and transparency, formulated in Section 3, and the degree and type of contact that Norwegian and Icelandic have experienced, discussed in Section 4, it is predicted that Norwegian shows a higher degree of transparency than Icelandic.

The research follows the method used by Leufkens (2015) in investigating the occurrence of the opacity features described in Section 2.2 and 2.3 in these two languages. Correspondingly, the study in principle assumes that a language that shows more opaque characteristics than another language is more opaque than that language. On the other hand, it has been argued that complex characteristics do not necessarily all contribute equally to complexity (Miestamo 2008:30; Deutscher 2009:249), and the same may hold for opaque characteristics and opacity, such that 
one cannot compare the overall degree of opacity of two languages by simply counting the opacity features. However, since Norwegian and Icelandic are closely related and, as the results will show, the transparency differences between these languages point almost all in the same direction, it nevertheless seems possible to make a comparison (compare Dammel \& Kürschner 2008:258-259; Miestamo 2008:30-31; Deutscher 2009:250).

Additionally, information about the cross-linguistic frequency of an opacity feature may help to determine the contribution of that feature to overall opacity. As more transparent features are likely to be easier to learn, they can be assumed to be more frequent (Miestamo 2008:37-38). Thus, the features lowest on the hierarchy in Figure 3, which are the most frequent, may be hypothesized to be the easiest and as such the least severe violations of transparency. Features low on the hierarchy may therefore be assumed to contribute less to the overall degree of opacity of a language than features high on the hierarchy. The present study therefore also takes into account the features' position on the hierarchy in the comparison of Norwegian and Icelandic. Note, however, that the high frequency of a feature may also be caused by other characteristics than only minor violation of transparency, such that a feature's position on the hierarchy is not an absolute indication of how much it contributes to opacity.

Furthermore, as transparency is a gradual rather than a binary notion (Leufkens 2015:14), the study investigates for each opacity feature not only whether or not it occurs in the languages, but also, if it occurs in both, to which extent it appears. This method is especially useful as the present study involves two highly similar languages, such that differences in transparency may lie in the extent to which particular features occur rather than in the presence vs. absence of features.

Finally, regarding Norwegian, the present study only investigates Bokmål. This is the written form that is used most in Norway today (Vikør 2001:56-57; Husby 2007:9). Bokmål also seems most interesting with respect to the hypothesis, as it is likely to reflect possible contact influence best, being based on urban Norwegian, which has experienced most contact with Danish and Low German.

\section{OPACITY FEATURES IN ICELANDIC AND NORWEGIAN}

In this section, the opacity features in Norwegian and Icelandic are presented. The full set of data and examples can be found in the Transparency in language - online dataset at http://transparency.humanities.uva.nl.

\subsection{Redundancy}

\subsubsection{Clausal agreement}

Both Icelandic and Norwegian show the redundancy feature clausal agreement. Icelandic clausal agreement involves nominative arguments, which are usually 
subjects, and their verbal and adjectival predicates, and objects and their adjectival predicates (Thráinsson 2007:2, 8). ${ }^{4}$ Icelandic verbal predicates show agreement in number and person, as in (1), while Icelandic adjectival predicates show agreement in number, gender and case, as in (2) and (3): ${ }^{5}$

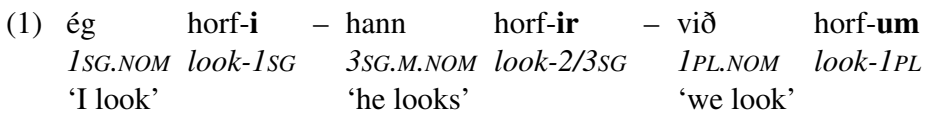

(Thráinsson 2007:8)

(2) Pess-ar hæn-ur eru gul-ar.

DEM-PL.F.NOM hen-PL.F.NOM be.3PL.PRS yellow-PL.F.NOM

'These hens are yellow.'

(Thráinsson 2007:2)

(3) Stelp-ur-nar hitt-u strák-a-na

girl-PL.F.NOM-DEF.PL.F.NOM meet-3PL.PST boy-PL.M.ACC-DEF.PL.M.ACC

full-a.

drunk-PL.M.ACC

'The girls met the boys drunk.' (= the boys were drunk)

(Thráinsson 2007:233)

In Norwegian, by contrast, clausal agreement is limited to subjects and their adjectival predicates, as in (4), and objects and their adjectival predicates, as in (5), as there is no agreement on verbs (Faarlund, Lie \& Vannebo 1997:386-387, 468):

(4) Hus-et er tom-t.

house-DEF.SG.N be.PRS empty-SG.N

'The house is empty.'

(Vinje 2005:103)

$\begin{array}{lll}\text { (5) De fant } \quad \text { hus-et } & \text { tom-t. } \\ \text { 3PL.NOM find.PST } & \text { house-DEF.SG.N } & \text { empty-SG.N } \\ \text { 'They found the house empty.' } & \end{array}$

(Faarlund et al. 1997:391)

Note, moreover, that the Norwegian predicative adjectives only agree with their subject and object in number and gender (Faarlund et al. 1997:764), and not in case, as Norwegian nouns and adjectives do not show case marking (Faarlund et al. 1997:316), apart from optional and relatively rare use of dative case-marking by older speakers of a number of dialects (Garbacz 2014). Furthermore, in Norwegian the agreement on predicative adjectives is not always applied consistently: in some styles and genres and in several dialects the agreement may simply be left out, while in other cases the form of the adjective depends on the semantic rather than the grammatical gender of the subject or object (Faarlund et al. 1997:765).

Since Norwegian clausal agreement is limited to number and gender on adjectival predicates, and this agreement is not even always applied, while Icelandic has a much 
more extensive agreement system, Norwegian may be considered more transparent with respect to this feature than Icelandic.

\subsubsection{Phrasal agreement}

Norwegian and Icelandic show phrasal agreement between nouns and their articles, possessives, demonstratives, quantifiers and adjectives. In Norwegian, all these elements, except for adjectives that combine with a definite noun, show number and gender agreement (Faarlund et al. 1997:202, 366), as shown in (6), whereas Icelandic additionally displays case agreement in all phrasal elements (Einarsson 1949:48-50, 65, 69-73), as in (7):

(6) et stor-t hus

INDF.SG.N big-SG.N house $(N)$

'a big house'

(Faarlund et al. 1997:390)

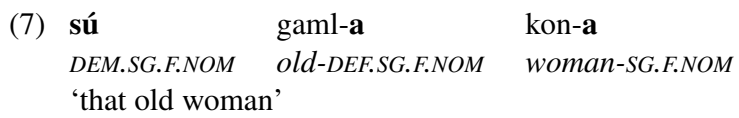

(Thráinsson 2007:113)

Moreover, in Norwegian gender agreement is not always applied consistently, as some dialects allow feminine words to show feminine agreement on the definite article but masculine agreement on the indefinite article (Faarlund et al. 1997: 151-152).

As in both languages the same types of elements are involved in phrasal agreement and the agreement expresses number and gender, but Norwegian does not show gender agreement consistently, and Icelandic additionally shows phrasal agreement in case, Norwegian is slightly more transparent with respect to phrasal agreement than Icelandic.

\subsubsection{Tense copying}

Tense copying is also present in both Norwegian and Icelandic (Askedal 1994:238; Thráinsson 1994:183). Norwegian shows tense copying in all embedded clauses. For instance, the embedded verb in the Norwegian example in (8) occurs in the past tense simply because the verb in the main clause is also in the past tense:

(8) Hun sa at hun studer-te språk- $\varnothing$.

3SG.F.NOM say.PST that 3SG.F.NOM study-PST language-INDF.PL

'She said that she studied languages.'

(Faarlund et al. 1997:573) 
Icelandic, on the other hand, only shows tense copying in embedded clauses with subjunctive verbs, which generally follow main clauses with non-factive verbs (Thráinsson 1994:183, 2007:395, 397). Thus, in example (9), which shows a main clause with a past tense verb sagð $i$ 'said', the subjunctive verb in the embedded clause must be the past tense form vari, while the present tense form sé is ungrammatical:

$\begin{array}{llll}\text { (9) Jón- } \varnothing & \text { sag-ð-i } & \text { að } & \text { tungl-ið } \\ \text { Jón-SG.M.NOM } & \text { say-PST-3SG } & \text { that } & \text { moon-DEF.SG.N.NOM } \\ \text { *sé / } & \text { væri } & \text { úr } & \text { ost-i. } \\ \text { be.3SG.PRS.SBJV } & \text { be.3SG.PST.SBJV } & \text { out.of } & \text { cheese-SG.M.DAT }\end{array}$

'Jón said that the moon is made of cheese.' (lit. Jón said that the moon were ... )

(Thráinsson 1994:183)

By contrast, Icelandic main clauses with (semi-)factive verbs combine with embedded clauses with indicative verbs, which do not show tense copying (Thráinsson 1994:183, 2007:397):

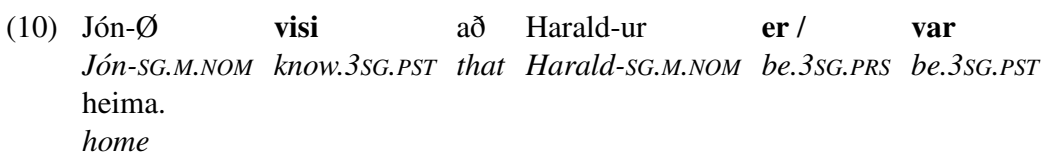

(Thráinsson 1994:183)

In (10), both a present tense and a past tense verb may occur in the embedded clause, depending on the intended meaning.

Since Norwegian uses tense copying in all its embedded clauses, while Icelandic only shows this feature in a subset of its embedded clauses, Norwegian may be argued to be more opaque regarding tense copying than Icelandic. However, Norwegian may also be considered more transparent than Icelandic in that tense copying is applied more regularly in Norwegian. In contrast to Icelandic and Old Norse, Norwegian does not productively form subjunctive verbs, such that the subjunctive is only used in a small number of fixed expressions (Faarlund et al. 1997:468-469) and embedded clauses always take indicative verbs. As a consequence, Norwegian has generalized the tense copying rule to all its embedded clauses. Because tense copying thus occurs less frequently in Icelandic but is more regular in Norwegian, the languages are considered equally transparent with respect to the feature tense copying.

\subsection{Discontinuity}

\subsubsection{Extraposition and extraction}

Both Norwegian and Icelandic show extraposition of various modifying elements from the noun phrase. In Norwegian relative clauses, prepositional phrases and 
infinitival constructions can be extraposed (Faarlund et al. 1997:277-278), whereas in Icelandic extraposition of relative clauses, prepositional phrases and embedded clauses can be found (Thráinsson 2007:362). An example of an extraposed prepositional phrase in Norwegian is shown in (11), while an example of an Icelandic extraposed relative clause appears in (12):

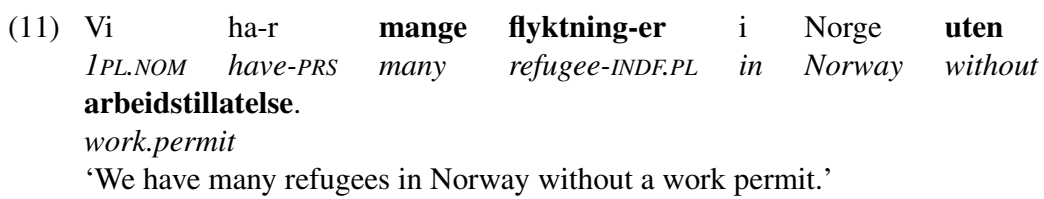

(Faarlund et al. 1997:278)
(12) Mað-ur-inn $\begin{array}{llll}\text { er } & \text { kom-in-n } & \text { að } & \text { hit-a } \\ \text { be.3SG.PRS } & \text { come-PTCP-SG.M.NOM } & \text { to } & \text { see-INF }\end{array}$ $\begin{array}{lll}\text { man-SG.M.NOM-DEF.SG.M.NOM } & \text { be.3SG.PRS con } \\ \text { pig sem hring-d-i i } & \text { í gærkvöld-i. }\end{array}$ 2SG.ACC that call-PST-3SG in last.night-SG.N.DAT 'The man has come to see you that called last night.'

(Thráinsson 2007:362)

The two languages also show extraction of prepositional phrases from the noun phrase (Faarlund et al. 1997:278; Jónsson 2008:406). However, only in Icelandic can some adverbs that modify adjectives be extracted from noun phrases as well (Thráinsson 2007:347). Thus, the adverb ofsalega 'extremely' may be extracted from the noun phrase ofsalega góður kennari 'extremely good teacher':
Ofsalega er María gód-ur kennari- $\varnothing$ ! extremely be.3SG.PRS María.SG.F.NOM good-SG.M.NOM teacher-SG.M.NOM 'What a great teacher María is!'

(Thráinsson 2007:347)

As both languages seem to display three types of extraposition, but Icelandic shows one more type of extracted modifiers than Norwegian, Icelandic appears to be slightly more opaque than Norwegian with respect to the feature extraposition and extraction.

\subsubsection{Raising}

Raising of embedded clause subjects to main clause subject and main clause object positions occurs in both Icelandic and Norwegian (Faarlund et al. 1997:1027, 1029; Thráinsson 2007:164, 413). In Norwegian, embedded clause objects can also easily 
become main clause subjects (Faarlund et al. 1997:1029). An example is shown in (14):

\begin{tabular}{|c|c|c|}
\hline 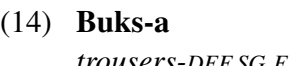 & $\begin{array}{l}\text { er } \\
\text { be } P R S\end{array}$ & 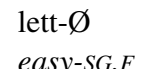 \\
\hline
\end{tabular}

'The trousers are easy to wash.'

(Faarlund et al. 1997:1029)

By contrast, raising of embedded clause objects to main clause subject positions seems to occur only marginally in Icelandic and is accepted by only few, mainly elderly, speakers (Comrie 1997:315; Thráinsson et al. 2007:105):

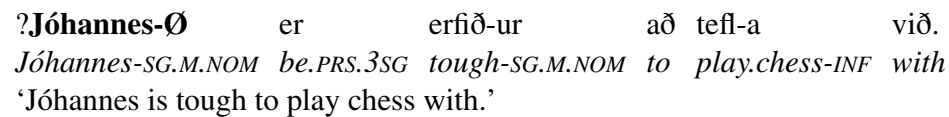

(Thráinsson et al. 2007:105)

As Icelandic is somewhat limited with respect to this last type of raising while Norwegian is not, Icelandic seems to be slightly more transparent than Norwegian with regard to this opacity feature.

\subsubsection{Circumfixes and infixes}

Neither Norwegian nor Icelandic shows circumfixes or infixes. The only affixes described for the two languages are suffixes and prefixes (Einarsson 1949, Faarlund et al. 1997). With respect to circumfixes and infixes the languages are thus equally transparent.

\subsubsection{Non-parallel alignment}

Both Norwegian and Icelandic show non-parallel alignment. Firstly, in both languages clitics occur, which are morphosyntactically independent words but phonologically part of another word (Kristoffersen 2000:331; Árnason 2011:263). A Norwegian example is the negation word $i k k e$, which may become cliticized to an inflected verb as $-k e$, such that the negation and the verb constitute a single phonological word, as evidenced by the single stressed syllable:

(16) $t ø r=k e$

['tœk.kə]

dare $=N E G$

'dares not'

(Kristoffersen 2000:335) 
Thus, words at the Morphosyntactic Level do not always correspond directly to words at the Phonological Level in Norwegian and Icelandic.

A second type of non-parallel alignment in Norwegian involves tonal accents, which apply to 'Accent Phrases' (Kristoffersen 2000:240). These Phrases start with a primary stressed syllable and contain all following non-stressed syllables before the next primary stressed syllable, which forms the beginning of a new Accent Phrase. Consequently, when the first syllable of a morphosyntactic word does not carry primary stress, this syllable belongs to the Accent Phrase of the preceding morphosyntactic word, which may even be part of the preceding morphosyntactic phrase. In this way, Accent Phrases, i.e. phonological phrases, do not always match morphosyntactic words or phrases.

In Icelandic, another type of non-parallel alignment can be found. Icelandic phonological words usually have main stress on their first syllable, but a few prefixes cannot be stressed (Árnason 2011:151,274). Consequently, when the first syllable of a morphosyntactic word is such a prefix, it cannot be the first syllable of a phonological word, since it does not carry main stress. Instead, it is phonologically part of the previous word, and the morphosyntactic and phonological word do thus not correspond. An example of a morphosyntactic word with such an unstressed prefix appears in (17):

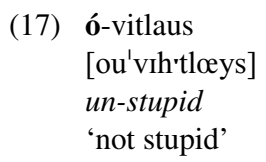

(Árnason 2011:274)

Since both Norwegian and Icelandic show at least two types of non-parallel alignment, they seem equally non-transparent regarding this feature.

\subsection{Fusion}

\subsubsection{Cumulation of tense/aspect/mood/evidentiality (TAME) and case}

Icelandic and Norwegian both display cumulation of case, number and, in some forms, gender in pronouns. However, while the Norwegian pronouns only show a nominative vs. accusative distinction (Faarlund et al. 1997:316), as the dative has disappeared almost completely from the language (Garbacz 2014) and the genitive has become a frozen clitic $=s$ (Askedal 2005a:231), Icelandic still systematically marks a dative and a genitive case in addition to the nominative and accusative (Einarsson 1949:68). Moreover, while both languages express gender in third person singular pronouns, only Icelandic shows gender distinctions in third person plural pronouns as well. 
Icelandic additionally displays cumulation of case, number and gender in full nouns, adjectives, determiners and quantifiers, as shown in example (7) above, leading for instance to a high number of nominal plural allomorphs in this language (Dammel \& Kürschner 2008:247-248). By contrast, Norwegian does not demonstrate cumulation in any other nominal elements.

Furthermore, Icelandic shows cumulation of mood and person and number of the nominative subject in weak verbs, in which the suffixes both distinguish indicative and subjunctive mood and express person and number of the subject (Thráinsson 2007:8-9). Norwegian, on the other hand, does not show cumulation of TAME and another category.

Since Icelandic shows more widespread cumulation of case and other categories than Norwegian and also displays cumulation of TAME and person and number, while Norwegian lacks this type of cumulation, Icelandic can be considered less transparent with respect to this feature than Norwegian.

\subsubsection{Suppletion}

Norwegian and Icelandic are equal in transparency regarding suppletion, as both show this feature only in the verb 'to be' (Einarsson 1949:104; Strandskogen \& Strandskogen 1980:33).

\subsubsection{Irregular stem formation}

Strong verbs mark their past tense by an irregular stem with a different vowel (ablaut) in both Norwegian (18) and Icelandic (19) (Einarsson 1949:30, 74; Faarlund et al. 1997:479):

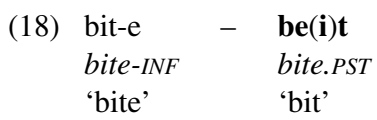

(Faarlund et al. 1997:487)

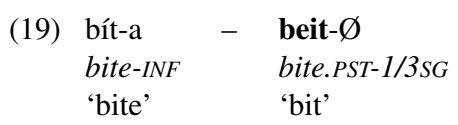

(Thráinsson 1994:159)

In Icelandic vowel alternations occur both in the indicative and in the subjunctive mood, while the Norwegian alternation is only relevant in the indicative mood, as Norwegian does not show a productive subjunctive mood.

In addition, a number of Icelandic nouns show irregular vowel alternations to mark the plural number, as in (20): 


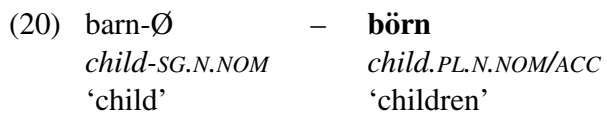

(Einarsson 1949:41)

Such vowel alternations indicating plural number occur in Norwegian as well, but Faarlund et al. (1997:165-166) mention only two nouns that undergo such alternations: mann 'man' with plural menn and gås 'goose' with plural gjess. All other examples of plural nouns with vowel alternations additionally show a regular plural morpheme, and thus display morphophonologically conditioned stem alternations rather than irregular stem formation (see Section 6.4.6). By contrast, irregular stem formations in plural nouns in the form of vowel alternations appear to be much more frequent in Icelandic, which displays at least 16 such examples (Einarsson 1949:37, 40, 41, 45; Jónsson 1984:25-32). Also Dammel \& Kürschner (2008:248-250) show that Icelandic has a high number of nouns that form their plural by changing the quality of the stem vowel.

As irregular stem formation is thus more widespread in Icelandic than in Norwegian, Icelandic seems to be more opaque regarding this feature than Norwegian.

\subsection{Form-based form}

\subsubsection{Grammatical gender}

Grammatical gender systems are seen as opaque as they involve groupings of nouns that are grammatically rather than semantically or pragmatically based, in contrast to semantic gender systems, which are relatively transparent (Audring 2014:10-11) and as such not included as an opacity feature in FDG (Leufkens 2015). Following Audring (2014:7), the present study assumes that the opacity of a grammatical gender system is dependent on the number of grammatical genders distinguished, as more gender classes entails more form-based form distinctions. Although the amount and types of gender agreement may also affect gender complexity (Audring 2014:11-13) and gender opacity, these are not dealt with in the feature grammatical gender as such agreement is considered separately through the feature phrasal agreement (see Section 6.1.2).

Icelandic and Norwegian both use a grammatical gender system with three genders, i.e. masculine, feminine and neuter (Faarlund et al. 1997:149; Thráinsson 2007:2), which surface through agreement between nouns and their articles, determiners, possessives, quantifiers and adjectives. However, in addition to the threegender system, Norwegian also has a two-gender system, used in several dialects, in which the masculine and feminine gender form one common gender (Faarlund et al. 1997:149-151). As Norwegian allows this more transparent gender system 
while Icelandic does not, Norwegian seems slightly more transparent with respect to grammatical gender than Icelandic.

\subsubsection{Nominal expletives}

Norwegian and Icelandic show nominal expletives in weather predicates and some other clauses without a semantic subject. Both Norwegian, in (21), and Icelandic, in (22), use the third person neuter nominative pronoun as nominal expletive (Thráinsson 1994:170; Faarlund et al. 1997:679-680):
(21) Det regn-er.
3SG.N.NOM rain-PRS
'It is raining.'

(Vinje 2005:223)

(22) Pað $\quad$ rign-d-i
3SG.N.NOM mikið rain-PST-3SG much in
'It rained a lot in Reykjavík then.'

(Thráinsson 2007:481)

Norwegian uses nominal expletives in all clauses without a semantic subject (Faarlund et al. 1997:679), i.e. det 'it' functions to avoid subjectless clauses. By contrast, Icelandic nominal expletives only occur clause-initially (Thráinsson 2007:480-481). The Icelandic nominal expletives thus function to fill the first position in the clause, when this position would otherwise remain empty.

Since both Norwegian and Icelandic obligatorily use the nominal expletive in their relevant contexts, i.e. in clauses without a subject and in clauses with an empty first position respectively, the two languages are equally opaque with respect to nominal expletives.

\subsubsection{Syntactic functions}

Following Leufkens (2015:84), a language is argued to show the feature syntactic functions if it displays neutralization of semantic and pragmatic roles in the arguments of intransitive predicates and/or if it uses a passive construction in which semantic roles are neutralized. In both phenomena, syntactic considerations rather than pragmatic or semantic ones determine the marking of arguments. Both Norwegian and Icelandic are opaque in their marking of arguments of intransitive predicates. In Norwegian, the argument of an intransitive predicate occurs in the first position of the clause, independent of its semantic or pragmatic function, unless another constituent is fronted to this position and the argument appears as the first nominal after the inflected verb, which always takes the second position (Faarlund et al. 1997:674, 859; Enger \& Kristoffersen 2000:238). In addition, Norwegian arguments of intransitive predicates do not take any formal marking to distinguish semantic or pragmatic roles. It must be noted, however, that such formal marking usually 
consists of case marking, which is generally almost absent in Norwegian, which only shows a nominative vs. accusative distinction in pronouns (Faarlund et al. 1997:316). On the other hand, pronominal arguments of intransitive predicates do not reflect pragmatic or semantic roles through case marking either. Thus, both agent and patient pronominal arguments, seen in (23) and (24), respectively, appear in the nominative case:

$\begin{array}{llll}\text { (23) Han } & \text { klatr-er } & \text { i } & \text { tre-et. } \\ \text { 3SG.M.NOM } & \text { climb-PRS } & \text { in } & \text { tree-DEF.SG.N }\end{array}$

'He climbs in the tree.'

(Vinje 2005:223)

$\begin{array}{lll}\text { (24) Han } & \text { sov-er. } \\ \text { 3SG.M.NOM } & \text { sleep-PRS } \\ \text { 'He sleeps.' } & \end{array}$

(Vinje 2005:156)

Thus, in Norwegian marking of arguments of intransitive predicates is syntactically determined.

In Icelandic, by contrast, arguments of intransitive predicates can have nominative, accusative, dative or genitive case (Jónsson 2003:130; Thráinsson 2007:159). To a considerable extent, the choice of case depends on the semantic function of the argument (Jónsson 2003:129). Thus, the theme argument in (25) takes accusative case, whereas the experiencer argument in (26) is in the dative case:

$\begin{array}{llllll}\text { (25) Snjó-a } & \text { leys-ir } & \text { sjaldan } & \text { par fyrr en í júni. } \\ \text { snow- } P L M A C C & \text { melt-3SG } & \text { rarely there until in June }\end{array}$

SnOW-PL.M.ACC melt-3sG rarely there until in June

'Snow rarely melts there before June.'

(Thráinsson 2007:203)

$\begin{array}{lll}\text { (26) Mér } & \text { er } & \text { kal-t } \\ \text { 1SG.DAT } & \text { be.3SG.PRS } & \text { cold-SG.N.NOM } \\ \text { 'I'm cold.' } & \end{array}$

(Thráinsson 2007:160)

Nevertheless, the case of the argument of an intransitive predicate is not completely predictable on the basis of its semantic function, as nominative arguments do not necessarily function as agents and also the other cases can express several semantic functions (Thráinsson 2007:206). Thus, the Icelandic alignment system is not completely semantic either. Moreover, the Icelandic system is very unpredictable, as one can neither fully depend on semantic nor on syntactic characteristics of arguments for their marking. Norwegian, on the other hand, is very systematic in using syntactic alignment only. Consequently, both Norwegian, which uses a syntactic alignment system, and Icelandic, which has a very irregular alignment system, are highly opaque regarding the marking of arguments of intransitive predicates. 
With respect to the passive, Norwegian and Icelandic are similar in using a periphrastic construction consisting of an auxiliary and the past participle (Faarlund et al. 1997:515; Thráinsson 2007:251). However, Norwegian additionally shows a synthetic passive with the middle marker $-s$, which evolved from the Old Norse middle marker $-s k$, related to the reflexive pronoun sik (Kemmer 1993: 185):

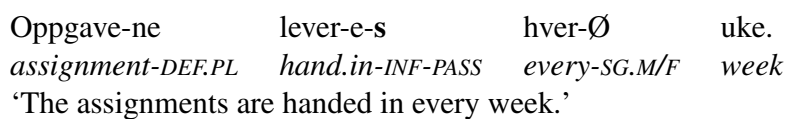

(Faarlund et al. 1997:514)

The Icelandic middle marker $-s t$ with the same origin has a passive-like use too (Thráinsson 2007:284). However, the Icelandic construction with -st does not allow the agent of the verb to be expressed in a 'by'-phrase, while the Norwegian synthetic passive does (Åfarli \& Sakshaug 2006:98; Thráinsson 2007:306). The Icelandic construction does thus not really show neutralization of semantic roles, but rather loss of the agent role (Leufkens 2015:84). As such it does not count as evidence for syntactic functions. The same holds for some other passive-like constructions in Icelandic (Thráinsson 2007:282).

Norwegian and Icelandic are thus both opaque in that they use syntactic functions, but as Icelandic has only one opaque passive construction, whereas Norwegian has two, Icelandic is slightly more transparent concerning this feature than Norwegian.

\subsubsection{Complexity determines constituent order/heavy shift}

Norwegian and Icelandic are alike in showing different positions for heavy and light objects: light objects, such as unstressed pronouns, have to precede adverbials, whereas heavy objects, i.e. full noun phrases, can also follow them (Faarlund et al. 1997:898; Thráinsson 2007:31-32). Norwegian examples are shown in (28) and (29), while Icelandic ones are included in (30):

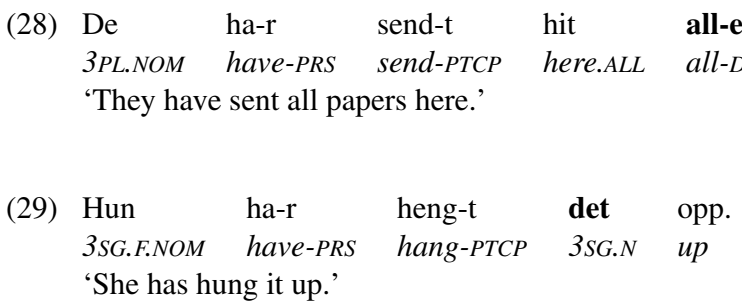

(Faarlund et al. 1997:899) 


$\begin{array}{llll}\text { (30) Jón- } \varnothing \quad & \text { las- } \varnothing & \text { aldrei } & \text { pessa } \\ \text { Jón-SG.M.NOM } & \text { read.PST-3SG } & \text { never } & \text { DEM.SG.F.ACC } \\ \text { bók } \quad / \quad{ }^{*} \text { hana. } & & \\ \text { book-SG.F.ACC } & \text { 3SG.F.ACC } & & \\ \text { 'Jón never read this book/*it.' } & & \end{array}$

(Thráinsson 2007:31-32)

Similarly, in both languages subjects show different positions depending on their weight: heavy subjects, such as noun phrases with many and/or complex modifiers, preferably occur somewhat later in the clause (Faarlund et al. 1997:880; Thráinsson 2007:361). As the weight of constituents seems to influence their position in the same way in Norwegian and Icelandic, the languages thus seem to be equally transparent with respect to this feature.

\subsubsection{Predominant head-marking}

Although Icelandic makes use of phrase-markers such as conjunctions (Einarsson 1949:175-177) and the negation word ekki (Thráinsson 2007:18), most functionmarking takes the form of suffixes, i.e. head-marking. Examples are the nominal suffixes for case, gender and number on nouns and adjectives (Einarsson 1949:47, 56), the suffixed articles (Einarsson 1949:48-49), and the suffixes marking tense, person and number on verbs (Einarsson 1949:96-99).

Norwegian too mainly shows head-markers, although phrase-marking is very frequent as well. Verbal categories such as present and past tense are generally expressed by suffixes and also participles, some passives and the infinitive take a suffix (Faarlund et al. 1997:469-474), while conjunctions (Faarlund et al. 1997:1116), prepositions (Faarlund et al. 1997:441), clitics, such as the indefinite articles, and the negation particle ikke are examples of phrase-markers.

Icelandic and Norwegian are thus both opaque because they show predominant head-marking, but as Norwegian, showing less inflection in general (Vikør 2001:40), displays head-marking less frequently than Icelandic, Norwegian seems to be slightly more transparent with regard to this feature than Icelandic.

\subsubsection{Morphophonologically conditioned stem alternation}

Both Norwegian (31) and Icelandic (32) show morphophonologically conditioned stem alternations in past participles of strong verbs, under influence of the past participle suffix:

$\begin{array}{lll}\text { (31) } \begin{array}{l}\text { drikk-er } \\ \text { drink-PRS } \\ \text { 'drink' }\end{array} & - & \text { drukk-et } \\ \text { drink-PTCP } & \text { 'drunk' }\end{array}$

(Faarlund et al. 1997:486) 

(32) brest
break.PRS.1SG
'(I) break'

brost-in-n
break-PTCP-SG.M.NOM
'broken'

(Einarsson 1949:97)

In addition, in both languages morphophonologically conditioned stem alternations appear in noun stems that are combined with a particular inflectional suffix. For instance, the Norwegian example in (33) and the Icelandic example in (34) show nouns that display stem alternations due to the presence of a plural suffix:

(33)

$$
\begin{array}{lll}
\text { natt } & - & \text { nett-er } \\
\text { night } & & \text { night-INDF.PL } \\
\text { 'night' } & \text { 'nights' }
\end{array}
$$$$
\begin{array}{lll}
\text { (34) } & \text { söng-ur } & \text { söngv-ar } \\
\text { song-SG.M.NOM } & & \text { Song-PL.M.NOM/ACC } \\
\text { 'song' } & \text { 'songs' }
\end{array}
$$

Finally, both Norwegian (35) and Icelandic (36) display morphophonologically conditioned stem alternations in various comparative and superlative forms of adjectives:

$\begin{array}{lllll}\text { (35) lang } & - & \text { leng-re } & - & \text { leng-st } \\ \text { long } & & \text { long-COMPA } & & \text { long-SUP } \\ \text { 'long' } & & \text { 'longer' } & & \text { 'longest' }\end{array}$
(36) stór- $\varnothing \quad-$ stær-r-i $\quad-$ stær-st-ur
big-SG.M.NOM big-COMPA-SG.M.NOM big-SUP-SG.M.NOM 'big' 'bigger' 'biggest'

(Einarsson 1949:58)

Both languages thus display morphophonologically conditioned stem alternations in exactly the same domains, due to the inheritance of these alternations from the Old Norse language, in which some of them were, however, regular, phonological alternations rather than morphophonologically conditioned ones (Haugen 1993:112135, 141, 182-191; Faarlund 2004:24-31, 53). Nevertheless, the occurrence of the alternations is much more limited in Norwegian than in Icelandic. Firstly, Faarlund et al. (1997:162-175) mention 36 Norwegian nouns with morphophonologically conditioned stem alternations, whereas Icelandic, according to Einarsson (1949:3345), includes 96 such nouns. Dammel \& Kürschner (2008:250) also note that Icelandic shows a high number of plural nouns with both a plural suffix and a stem alternation compared to other Germanic languages. Secondly, based on Faarlund et al. (1997:353-356) and Einarsson (1949:58-59), more comparative and superlative 
forms with morphophonologically conditioned stem alternations seem to occur in Icelandic than in Norwegian. Thus, Norwegian is somewhat more transparent than Icelandic with respect to this feature.

\subsubsection{Morphologically conditioned affix alternation (conjugation/declension)}

Norwegian and Icelandic both have two conjugation classes: weak and strong verbs (Einarsson 1949:74; Faarlund et al. 1997:479). While weak verbs use a suffix to mark the past tense, as in the Norwegian example in (37) and the Icelandic example in (38), strong verbs show irregular stem formation, as shown in (18) for Norwegian and in (19) for Icelandic in Section 6.3.3 above.

(37) kast-et

throw-PST

'threw'

(Faarlund et al. 1997:481)

(38) dug-ð-i

suffice-PST-1/3SG

'sufficed'

(Thráinsson 1994:159)

By contrast, declension classes for nouns can only be recognized in Icelandic. This language distinguishes a strong declension class with genitive singular suffixes ending in a consonant, as in (39), and a weak declension class with genitive singular suffixes ending in a vowel, as in (40) (Einarsson 1949:32):

(39) hest-s

horse-SG.M.GEN

'horse'

(Thráinsson 1994:153)

(40) tím-a

time-SG.M.GEN

'time'

(Thráinsson 1994:153)

Although Norwegian nouns may be divided into classes based on their plural affixes, the choice between these affixes is partly phonologically conditioned (Faarlund et al. 1997:163, 171, see Section 6.4.8), such that they do not reflect morphologically conditioned declension classes. As Norwegian and Icelandic show the same number of conjugation classes, but Icelandic in addition makes use of declension classes, Icelandic may be seen as more opaque in its morphologically conditioned affix alternations than Norwegian. 


\subsubsection{Morphophonologically conditioned affix alternation}

Both Norwegian and Icelandic show morphophonologically conditioned affix alternations. Norwegian and Icelandic weak verbs take past tense affixes which alternate between four different forms, depending on the phonological form of the weak verb (Einarsson 1949:74, 82; Faarlund et al. 1997:482-483). Both languages also display morphophonologically conditioned affix alternations in the nominal domain. However, while Icelandic shows several such alternations, such as the nominative plural affix alternating between -ar and -ir in the strong masculine declension and between - $a r$, -ir and - $u r$ in the strong feminine declension (Thráinsson 1994:153), and the dative singular suffix alternating between $-\varnothing,-u$ and $-i$ in the strong feminine declension (Einarsson 1949:38), in Norwegian only the choice of the plural zero suffix instead of the regular plural suffix -er with neuter nouns of only one syllable, exemplified in (41), can be called a morphophonologically conditioned alternation:

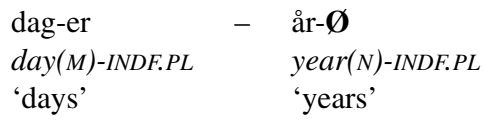

(Faarlund et al. 1997:161, 172)

Since the morphophonologically conditioned affix alternations are more widespread in Icelandic, this language can be said to be somewhat more opaque with respect to this feature than Norwegian.

\subsubsection{Phonologically conditioned stem alternation}

Norwegian and Icelandic display several phonologically conditioned stem alternations. An example in Norwegian is cluster simplification, which involves the loss of one or two stem-final consonants when a sonorant + obstruent + obstruent cluster arises through affixation (Kristoffersen 2000:109), as in (42):

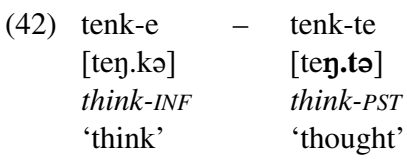

(Kristoffersen 2000:109)

In addition, Norwegian shows nasal assimilation, a process in which a stem-final /n/ adapts its place of articulation to a following stop (Kristoffersen 2000:321).

Icelandic phonologically conditioned stem alternations are, for instance, devoicing of stem-final sonorants before /p, t, k, s/, shown in (43), and fricativization 
of stem-final /p, k/ preceded by a vowel and followed by /t/, exemplified in (44) (Thráinsson 1994:151):

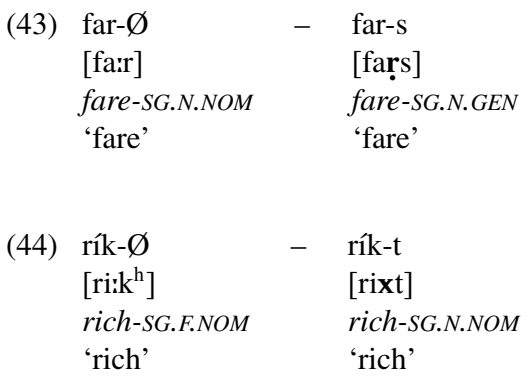

(Thráinsson 1994:151)

(Thráinsson 1994:151)

As both Norwegian and Icelandic show several types of phonologically conditioned stem alternations, the languages seem to be equal in transparency regarding this feature.

\subsubsection{Phonologically conditioned affix alternation}

Norwegian and Icelandic also both have affixes that display phonologically conditioned alternations. Norwegian examples are the plural and definite agreement suffixes on adjectives, both unstressed $-e$, which become $-\varnothing$ when they attach to a stem that ends in $-e$ :

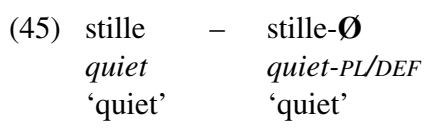

(Faarlund et al. 1997:375)

Through this alternation a sequence of two unstressed vowels is avoided, and also the occurrence of two vowels of the same quality in a single syllable, which does not exist in Norwegian phonology (Kristoffersen 2008:30), is prevented. Other examples are the neuter agreement affix $-t$ on adjectives and the past participle affix $-t$, which both change into $-\varnothing$ when they attach to a stem that ends in $-t$, such that there is no geminate at the end of a syllable (Kristoffersen 2000: 214).

In Icelandic the singular definite article suffixes alternate between a variant with and without a vowel, depending on the form of the noun that they attach to: suffixes with a vowel attach to inflected nouns ending in a consonant, whereas suffixes without a vowel combine with inflected nouns that end in a vowel (Einarsson 1949:49-50), as shown in (46): 
(46)

hest-ur-inn
horse-SG.M.NOM-DEF.SG.M.NOM
'the horse'

- tím-i-nn

time-SG.M.NOM-DEF.SG.M.NOM

'the time'

(Einarsson 1949:48)

In addition, the Icelandic masculine suffix -ur, used both for nominal and adjectival nominative singular, alternates with $-r$. The suffix $-u r$ is used when the stem ends in a consonant, whereas the suffix $-r$ is used with nouns ending in a vowel (Einarsson 1949:33, 51):

(47)

$\begin{array}{lll}\text { hest-ur } & - & \text { mó-r } \\ \text { horse-SG.M.NOM } & \text { peat-SG.M.NOM } \\ \text { 'horse' } & \text { 'peat' }\end{array}$

(Einarsson 1949:33)

Since these examples show that both Norwegian and Icelandic display several phonologically conditioned affix alternations, both languages can be considered opaque with respect to this feature.

\section{DISCUSSION AND CONCLUSION}

An overview of the opacity features in Norwegian and Icelandic is now presented in Table 5.

As can be seen in this table, Norwegian and Icelandic both appear to be highly opaque, showing 19 of the 20 opacity features investigated. Note, moreover, that they display all of the features included in the implicational hierarchy in Figure 3. A comparison of these results and those presented in Leufkens (2015) suggests that Icelandic and Norwegian belong to the most opaque languages of the world. The only feature that Icelandic and Norwegian both lack is the feature infixes/circumfixes. The presence or absence of this feature, being a discontinuity feature, is however not related to the general degree of opacity of a language, and this feature is therefore not included in the hierarchy, as discussed in Section 2.3. The absence of infixes and circumfixes in Icelandic and Norwegian is thus not inconsistent with their overall opacity. Since both languages display all features that are part of the hierarchy, they cannot be used to further test the implicational hierarchy that Leufkens (2015) proposes or to test Leufkens' conclusion that features violating phonological transparency are violated more easily than features that involve syntacticity.

Although the two languages are identical in the types of opacity and the set of opacity features that they show, differences in the degree to which the various features are present in both languages can be found. While Icelandic and Norwegian exhibit many of the features to an equal extent, even more features appear to be more frequent 


\begin{tabular}{lll}
\hline Feature & Norwegian & Icelandic \\
\hline Clausal agreement & + & $+\uparrow$ \\
Phrasal agreement & + & $+\uparrow$ \\
Extraposition/ extraction & + & $+\uparrow$ \\
Cumulation & + & $+\uparrow$ \\
Irregular stem formation & + & $+\uparrow$ \\
Grammatical gender & + & $+\uparrow$ \\
Predominant head-marking & + & $+\uparrow$ \\
Morphophonologically conditioned stem alternation & + & $+\uparrow$ \\
Morphologically conditioned affix alternation & + & $+\uparrow$ \\
Morphophonologically conditioned affix alternation & + & $+\uparrow$ \\
Tense copying & + & + \\
Circumfixes/infixes & - & - \\
Non-parallel alignment & + & + \\
Suppletion & + & + \\
Nominal expletives & + & + \\
Complexity determines constituent order & + & + \\
Phonologically conditioned stem alternation & + & + \\
Phonologically conditioned affix alternation & + & + \\
Raising & $+\uparrow$ & + \\
Syntactic functions & $+\uparrow$ & + \\
\hline Symbols: - indicates the absence of a feature, + indicates the presence of a feature, $\uparrow$ indicates that a feature is clearly \\
more prominent in one language compared to the other language & &
\end{tabular}

Table 5. Opacity features in Norwegian and Icelandic.

and widespread in Icelandic than in Norwegian. Consequently, as predicted on the basis of the language contact that the two languages have experienced, Norwegian seems to be more transparent than Icelandic.

This difference between the two languages seems largely due to an increase in transparency with respect to a number of features in Norwegian compared to Old Norse. While Old Norse showed clausal agreement with both verbal and adjectival predicates (Haugen 1993:254-255), Norwegian does no longer display agreement on verbs. Similarly, phrasal agreement is more limited in Norwegian compared to Old Norse, which also had agreement in case (Faarlund 2004:16), which Norwegian lacks. Additionally, Old Norse displayed cumulation of case and person and number in all nominal elements (Haugen 1993:157, 167; Faarlund 2004:68, 74) and cumulation of mood and person and number of the subject in verbs (Faarlund 2004:49-50), while in Norwegian cumulation is restricted to pronouns. Moreover, Norwegian seems to be in the process of losing one of the three genders that were present in Old Norse (Haugen 1993:94). Finally, nominal declensions occurred in Old Norse (Faarlund 2004:23), but are no longer present in Norwegian. Over the centuries, Norwegian has thus increased its transparency with respect to several features. Icelandic, 
by contrast, still shows these opacity features to the same extent as Old Norse did.

Note that the above findings are only based on Bokmål; Nynorsk seems to be somewhat more similar to Old Norse and Icelandic than Bokmål with respect to many features and may thus be more opaque than Bokmål. For example, Nynorsk shows clausal agreement with adjectival predicates more consistently than Bokmål (Faarlund et al. 1997:765), uses always three and not two grammatical genders (Faarlund et al. 1997:150-151), and still shows some nominal declensions, at least in the more conservative varieties (Faarlund et al. 1997:193; Vikør 2001:207). However, a thorough study of transparency in Nynorsk is necessary before any conclusions regarding the differences between Bokmål and Nynorsk can be drawn.

Importantly, many of the changes towards transparency in Norwegian Bokmål seem to be related to an overall simplification of inflection that has taken place in the language (Haugen 1976:65; Vikør 2001:44; Askedal 2005a:1872; Jahr 2008:246). For instance, the great reduction in the use of case marking seems to be responsible for the higher degree of transparency with respect to phrasal agreement, cumulation of case and another semantic category, and some morphophonologically conditioned affix alternations. Similarly, the loss of verbal morphology is involved in the disappearance of clausal agreement on verbs and the cumulation of mood and person and number of the subject. Crucially, it has often been argued that this inflectional simplification is largely due to language contact, especially with Low German (Haugen 1976:65; Trudgill 2000; Vikør 2001:44; Jahr 2008:246-247). In this way, the increasing transparency in Norwegian seems to be directly connected to language contact. ${ }^{6}$

The decrease in transparency in Norwegian generally seems to involve contextual and not inherent inflection. For instance, much of the agreement morphology is lost, whereas tense inflection on verbs and number inflection on nouns has been retained. This observation corresponds to Roberts \& Bresnan's finding that in pidginization contextual inflection rather than inherent inflection disappears, which they argue may be explained by the higher semantic relevance of inherent inflection (Roberts \& Bresnan 2008:292). With respect to transparency, contextual inflection, reflecting already present syntactic information (Booij 1993:30), tends to lead to redundancy and form-based form. Furthermore, Kusters (2003:51) notes that inherent inflectional categories are generally the easiest inflectional categories for L2 learners, which may further explain the loss of contextual rather than inherent inflection.

Although the study overall shows that Norwegian, a language that has experienced much language contact of the type that is hypothesized to lead to increasing transparency, is more transparent than the more isolated language Icelandic, the results also contain two counterexamples to this general tendency. Firstly, Icelandic seems slightly more transparent than Norwegian with respect to raising, as not all speakers accept raising of embedded clause objects, whereas this 
type of raising is common in Norwegian. Interestingly, Old Norse did show raising of embedded clause objects (Faarlund 2004:103), which means that Icelandic has become more transparent whereas Norwegian has kept the same degree of opacity as Old Norse with respect to this feature. However, the feature raising is not included in the implicational hierarchy of opacity features, since it, like all discontinuity features, does not correlate with the general degree of transparency of a language (Leufkens 2015:136). In this way, the higher degree of transparency of Icelandic with respect to this feature is not too unexpected.

Secondly, Norwegian is somewhat more opaque than Icelandic with respect to syntactic functions, in that Norwegian shows two different passive constructions whereas Icelandic has only one passive construction. Relevant here is that Norwegian has extended the use of its middle marker $-s$ to real passive functions, whereas the Icelandic middle marker $-s t$ with the same origin has not, as it does not allow agents to be expressed in a 'by'-phrase. This difference corresponds to the general observation that Norwegian over the centuries has been more innovative than Icelandic. It may further be noted that the feature syntactic functions is lowest on the implicational hierarchy of opacity features in Figure 3, i.e. it is highly frequent, which may be because it provides a relatively small contribution to overall opacity. Moreover, with respect to the marking of arguments of intransitive predicates, which is also involved in the feature syntactic functions, both Norwegian and Icelandic are highly opaque, such that the difference between the two languages with respect to the feature may be argued to be rather small. Therefore, the counterexample concerning syntactic functions does not weaken the general tendency that Norwegian is more transparent than Icelandic too seriously either.

Despite the two counterexamples, the findings generally show that Norwegian has increased its transparency whereas Icelandic has not. In addition, it appears that the growing transparency in Norwegian is indeed likely to have been due to the language contact that the language has experienced. The study thus supports the hypothesis that extensive but short-term language contact with adult outsiders may lead to an increase in transparency. In this way, the results add to the research on the relation between transparency and language contact, showing that such a relation does not only hold for creole languages, but may also lead to differences between languages with a highly similar genealogical background.

\section{ACKNOWLEDGEMENTS}

I would like to thank Kees Hengeveld, Luisa Seguin, Maud Westendorp, three anonymous $N J L$ reviewers and $N J L$ editor Matti Miestamo for their constructive feedback. I am also grateful to the participants of IC-FDG-2016 for valuable comments. 


\section{NOTES}

1. The near-universal features are nominal apposition, plural concord, temporal concord and spatial concord, whereas the multiple expression of pragmatic information, negative concord and modal concord are assumed to be immeasurable, at least on the basis of data from reference grammars.

2. Leufkens' findings are not tested statistically as the sample size of 22 languages is too small for such testing and her study is a qualitative rather than a quantitative one (Leufkens 2015:103).

3. Some authors have also considered the Black Death as an important event for Norwegian language development, arguing that it has led to considerable, sudden, simplifying changes in the Norwegian language in the 14th century (Haugen 1993:19-20; Torp \& Vikør 1994:116-117; Otnes \& Aamotsbakken 2012:71). However, others, such as Mæhlum (2000), do not believe that this catastrophe has had a direct impact on language development. Mæhlum argues instead that the changes that occurred were gradual ones that did not occur abruptly after 1349-1350. Moreover, she emphasizes that the plague has not been used as an explanation for the same types of changes in Swedish and Danish. As the possible role of the Black Death in the changes addressed in the present research thus remains unclear, it is not discussed further in the paper.

4. Although Icelandic nominative arguments are typically subjects, Icelandic does not show a direct relationship between the case and the grammatical relation of arguments (Thráinsson 2007:156). Instead, both subjects and objects may be marked by nominative, accusative, dative as well as genitive case (Thráinsson 2007:167, see Section 6.4.3). Icelandic subjects are therefore not characterized by a particular case, but can be recognized on the basis of a number of tests, such as inversion with the finite verb, antecedent properties and ellipsis (Thráinsson 2007:161-165).

5. Glossing according to the Leipzig Glossing Rules (http://www.eva. mpg.de/lingua/resources/glossing-rules.php). Abbreviations: 1, 2, $3=$ first, second, third person; $\mathrm{ACC}=$ accusative; $\mathrm{ALL}=$ allative; $\mathrm{COMPA}=$ comparative adjective; $\mathrm{DAT}$ $=$ dative $; \mathrm{DEF}=$ definite DEM $=$ demonstrative; $\mathrm{F}=$ feminine $; \mathrm{GEN}=$ genitive $;$ INDF $=$ indefinite; $\mathrm{INF}=$ infinitive; $\mathrm{M}=$ masculine; $\mathrm{N}=$ neuter; $\mathrm{NEG}=$ negation; $\mathrm{NOM}=$ nominative; PASS $=$ passive; $\mathrm{PL}=$ plural; $\mathrm{PRS}=$ present $; \mathrm{PST}=$ past $; \mathrm{PTCP}=$ participle; $\mathrm{SBJV}=$ subjunctive; $\mathrm{SG}=$ singular; $\mathrm{SUP}=$ superlative adjective.

6. As pointed out by a reviewer, loss of case marking does not have to be due to a general development towards more transparency, but can also be a form of grammatical replication, i.e. the copying of grammatical structures from a model language into a replica language in a contact setting (Heine \& Kuteva 2005:2). However, Low German as it was used at the time of the contact with Norwegian, i.e. Middle Low German, distinguished the same cases as Old Norse: nominative, accusative, dative and genitive (Askedal 2005b:3). It is therefore improbable that the loss of case marking in Norwegian is due to grammatical replication of the Middle Low German case system in terms of the number and types of cases. Moreover, Askedal (2005b:3-9) argues that while Middle Low German showed a 'selective' agreement-marking system, in which only a subset of the constituents in a phrase showed distinctive agreement marking for number, gender and case, Old Norse had and present-day Norwegian still has a 'distributive' agreementmarking system, which shows agreement marking all constituents in a phrase. In Old Norse, number, gender and case were marked in this way, whereas in present-day Norwegian it indicates number, gender and definiteness. Thus, also with respect to the agreement 
marking system, in which case used to be involved, direct grammatical replication seems unlikely.

\section{REFERENCES}

Åfarli, Tor A. \& Laila Sakshaug. 2006. Grammatikk: Syntaks og morfologi med norsk $i$ sentrum [Grammar: Syntax and morphology with a focus on Norwegian]. Oslo: Det Norske Samlaget.

Aikhenvald, Alexandra Y. 2007. Typological distinctions in word-formation. In Timothy Shopen (ed.), Language Typology and Syntactic Description, vol. 3: Grammatical Categories and the Lexicon, 2nd edn., 1-65. Cambridge: Cambridge University Press.

Almenningen, Olaf, Thore A. Roksvold, Helge Sandøy \& Lars S. Vikør (eds.). 1981. Språk

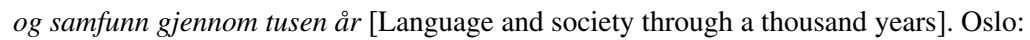
Universitetsforlaget.

Árnason, Kristján. 2011. The Phonology of Icelandic and Faroese (The Phonology of the World's Languages). Oxford: Oxford University Press.

Askedal, John O. 1994. Norwegian. In König \& van der Auwera (eds.), 219-270.

Askedal, John O. 2005a. The typological development of the Nordic languages II: Morphology and syntax. In Bandle et al. (eds.), 1872-1886.

Askedal, John O. 2005b. Typological reflections on loss of morphological case in Middle Low German and in the Mainland Scandinavian languages. In Michael Fortescue, Eva Skafte Jensen, Jens E. Mogensen \& Lene Schøsler (eds.), Historical Linguistics 2003: Selected Papers from the 16th International Conference on Historical Linguistics, Copenhagen, 11-15 August 2003 (Current Issues in Linguistic Theory 257), 1-19. Amsterdam: John Benjamins.

Audring, Jenny. 2014. Gender as a complex feature. Language Sciences 43, 5-17.

Bandle, Oskar, Kurt Braunmüller, Ernst H. Jahr, Allan Karker, Hans-Peter Naumann \& Ulf Teleman (eds.). 2005. The Nordic Languages: An International Handbook of the History of the North Germanic Languages, vol. 2. Berlin: Walter de Gruyter.

Booij, Geert. 1993. Against split morphology. In Geert Booij \& Jaap van Marle (eds.), Yearbook of Morphology 1993, 27-50. Dordrecht: Kluwer.

Braunmüller, Kurt. 1997. Communication strategies in the area of the Hanseatic league: The approach by semi-communication. Multilingua 16(4), 365-373.

Bull, Tove. 2005. Special linguistic developments in 19th-century Norway. In Bandle et al. (eds.), 1468-1475.

Comrie, Bernard. 1997. Tough movement and its analogs in Germanic languages. In Stig Eliasson \& Ernst H. Jahr (eds.), Language and its Ecology: Essays in Memory of Einar Haugen, 303-323. Berlin: Mouton de Gruyter.

Dahl, Östen. 2004. The Growth and Maintenance of Linguistic Complexity (Studies in Language Companion Series 71). Amsterdam: John Benjamins.

Dammel, Antje \& Sebastian Kürschner. 2008. Complexity in nominal plural morphology: A contrastive survey of ten Germanic languages. In Miestamo et al. (eds.), 243-262.

Deutscher, Guy. 2009. 'Overall complexity': A wild goose chase? In Sampson et al. (eds.), 243-251.

Duke, Janet. 2010. Gender reduction and loss in Germanic: The Scandinavian, Dutch, and Afrikaans case studies. In Antje Dammel, Sebastian Kürschner \& Damaris Nübling 
(eds.), Kontrastive Germanistische Linguistik, vol. 2, 643-672. Hildesheim: Georg Olms Verlag.

Einarsson, Stefán. 1949. Icelandic: Grammar, Texts, Glossary. Baltimore, MD: The Johns Hopkins Press.

Ellis, Nick C. \& Richard Schmidt. 1997. Morphology and longer distance dependencies.

Studies in Second Language Acquisition 19(2), 145-171.

Enger, Hans-Olav \& Kristian E. Kristoffersen. 2000. Innføring i norsk grammatikk:

Morfologi og syntaks [Introduction to Norwegian grammar: Morphology and syntax].

Oslo: Landslaget for norskundervisning (LNU)/Cappelen.

Faarlund, Jan T. 1994. Old and Middle Scandinavian. In König \& van der Auwera (eds.), 38-71.

Faarlund, Jan T. 2004. The Syntax of Old Norse: With a Survey of the Inflectional Morphology and a Complete Bibliography. Oxford: Oxford University Press.

Faarlund, Jan T., Svein Lie \& Kjell I. Vannebo. 1997. Norsk referansegrammatikk

[Norwegian reference grammar]. Oslo: Universitetsforlaget.

Garbacz, Piotr. 2014. Morphological dative in Norwegian dialects. Nordic Atlas of Language Structures Journal 1, 72-86.

Giegerich, Heinz J. 1992. English Phonology: An Introduction (Cambridge Textbooks in Linguistics). Cambridge: Cambridge University Press.

Haugen, Einar. 1976. The Scandinavian Languages: An Introduction to their History. London: Faber and Faber.

Haugen, Odd E. 1993. Grunnbok i norrønt språk [An elementary introduction to Old Norse]. Oslo: Gyldendal.

Heine, Bernd \& Tania Kuteva. 2005. Language Contact and Grammatical Change (Cambridge Approaches to Language Contact). Cambridge: Cambridge University Press.

Hengeveld, Kees \& Sterre Leufkens. 2017. Transparent and non-transparent languages. Ms., University of Amsterdam.

Hengeveld, Kees \& J. Lachlan Mackenzie. 2008. Functional Discourse Grammar: A Typologically-based Theory of Language Structure. Oxford: Oxford University Press.

Housen, Alex \& Hannelore Simoens. 2016. Introduction: Cognitive perspectives on difficulty and complexity in L2 acquisition. Studies in Second Language Acquisition 38(2), $163-175$.

Husby, Olaf. 2007. Norway - a multilingual society. Forum 9(2), 8-10.

Jahr, Ernst H. 1999. Sociolinguistics in historical language contact: The Scandinavian languages and Low German during the Hanseatic period. In Ernst H. Jahr (ed.), Language Change: Advances in Historical Sociolinguistics, 119-139. Berlin: Mouton de Gruyter.

Jahr, Ernst H. (ed.). 2000. Språkkontakt: Innverknaden frå nedertysk på andre nordeuropeiske språk [Language contact: Low German influence on other north European languages]. København: Nordisk Ministerråd.

Jahr, Ernst H. 2008. Historical sociolinguistics: The role of Low German language contact in the Scandinavian typological shift of the late Middle Ages. In Geirr Wiggen, Tove Bull \& Marit A. Nielsen (eds.), Språkhistorie og språkkontakt: Festskrift til Ernst Håkon Jahr på 60-årsdagen 4. mars 2008 [Language history and language contact: Festschrift for Ernst Håkon Jahr on the occasion of his 60th birthday on 4 March 2008], 246-257. Oslo: Novus Forlag. 
Jónsson, Jóhannes G. 2003. Not so quirky: On subject case in Icelandic. In Ellen Brandner \& Heike Zinsmeister (eds.), New Perspectives on Case Theory, 129-165. Stanford, CA: CSLI Publications.

Jónsson, Jóhannes G. 2008. Preposition reduplication in Icelandic. In Sjef Barbiers,

Olaf Koeneman, Marika Lekakou \& Margreet van der Ham (eds.), Microvariation in Syntactic Doubling (Syntax and Semantics 36), 403-418. Bingley: Emerald.

Jónsson, Jón H. 1984. Islandsk grammatikk for utlendinger [Icelandic grammar for foreigners]. Reykjavík: Málvísindastofnun Háskóla Íslands.

Karlsson, Stefán. 2004. The Icelandic Language (R. McTurk, Trans.). London: Viking Society for Northern Research, University College London.

Kemmer, Suzanne. 1993. The Middle Voice. Amsterdam: John Benjamins.

König, Ekkehard \& Johan van der Auwera (eds.). 1994. The Germanic Languages. London: Routledge.

Kortmann, Bernd \& Benedikt Szmrecsanyi. 2012. Linguistic Complexity: Second Language Acquisition, Indigenization, Contact (Linguae \& Litterae 13). Berlin: Walter de Gruyter.

Kristoffersen, Gjert. 2000. The Phonology of Norwegian (The Phonology of the World's Languages). Oxford: Oxford University Press.

Kristoffersen, Gjert. 2008. Kort innføring i norsk fonologi [A brief introduction to Norwegian phonology]. Bergen: Institutt for lingvistiske, litterære og estetiske studier, Universitetet i Bergen.

Kusters, Wouter. 2003. Linguistic Complexity: The Influence of Social Change on Verbal Inflection. Ph.D. dissertation, Leiden University.

Leonard, Stephen P. 2011. Relative linguistic homogeneity in a new society: The case of Iceland. Language in Society 40(2), 169-186.

Leufkens, Sterre. 2013. The transparency of creoles. Journal of Pidgin and Creole Languages 28(2), 323-362.

Leufkens, Sterre. 2015. Transparency in Language: A Typological Study. Ph.D. dissertation, University of Amsterdam.

Lupyan, Gary \& Rick Dale. 2010. Language structure is partly determined by social structure. PLOS ONE 5(1), 1-10.

Mæhlum, Brit. 2000. Social catastrophies as explanation in historical linguistics: A historiographical and critical discussion of a central topic in the investigation of Norwegian language history. In Jahr, (ed.), 87-94.

Mæhlum, Brit. 2005. Sociolinguistic structures chronologically III: Norwegian. In Bandle et al. (eds.), 1907-1922.

Maitz, Péter \& Attila Németh. 2014. Language contact and morphosyntactic complexity: Evidence from German. Journal of Germanic Linguistics 26(1), 1-29.

McWhorter, John. 2001. The world's simplest grammars are creole grammars. Linguistic Typology 5(2-3), 125-166.

McWhorter, John. 2007. Language Interrupted: Signs of Non-native Acquisition in Standard Language Grammars. New York: Oxford University Press.

Miestamo, Matti. 2008. Grammatical complexity in a cross-linguistic perspective. In Miestamo et al. (eds.), 23-42.

Miestamo, Matti, Kaius Sinnemäki \& Fred Karlsson (eds.). 2008. Language Complexity: Typology, Contact, Change (Studies in Language Companion Series 94). Amsterdam: John Benjamins.

Newmeyer, Frederick J. \& Laurel B. Preston. 2014. Measuring Grammatical Complexity. Oxford: Oxford University Press. 
Nichols, Johanna. 1986. Head-marking and dependent-marking grammar. Language 62(1), 56-119.

Otnes, Hildegunn \& Bente Aamotsbakken. 2012. Tekst i tid og rom: Norsk språkhistorie [Text in time and space: Norwegian language history], 4th edn. Oslo: Det Norske Samlaget.

Roberts, Sarah J. \& Joan Bresnan. 2008. Retained inflectional morphology in pidgins: A typological study. Linguistic Typology 12(2), 269-302.

Roksvold, Thore A. 1981. Reformasjonen og eineveldet (1536-1814). In Almenningen et al. (eds.), 46-53.

Røyneland, Unn. 2003. Språk- og dialektkontakt. In Brit Mæhlum, Gunnstein Akselberg, Unn Røyneland \& Helge Sandøy (eds.), Språkmøte: Innføring i sosiolingvistikk [Meeting in language: Introduction to sociolinguistics], 44-69. Oslo: Cappelen.

Sampson, Geoffrey, David Gil \& Peter Trudgill (eds.). 2009. Language Complexity as an Evolving Variable (Studies in the Evolution of Language 13). Oxford: Oxford University Press.

Sandøy, Helge. 1981, Seinmellomalderen (1350-1536). In Almenningen et al. (eds.), 36-45.

Sandøy, Helge. 2004. Types of society and language change in the Nordic countries. In Britt-Louise Gunnarsson, Lena Bergström, Gerd Eklund, Staffan Fridell, Lise H. Hansen, Angela Karstadt, Bengt Nordberg, Eva Sundgrenand \& Mats Thelander (eds.), Language Variation in Europe: Papers from the Second International Conference on Language Variation in Europe, ICLaVE 2, 53-76. Uppsala: Uppsala Universitet.

Sinnemäki, Kaius. 2008. Complexity trade-offs in core argument marking. In Miestamo et al. (eds.), 67-88.

Sinnemäki, Kaius. 2009. Complexity in core argument marking and population size. In Sampson et al. (eds.), 126-140.

Skard, Vemund. 1972. Norsk språkhistorie [Norwegian language history], vol. 2: 1523-1814. Oslo: Universitetsforlaget.

Skard, Vemund. 1976. Norsk språkhistorie [Norwegian language history], vol. 1: Til 1523, 3rd edn. Oslo: Universitetsforlaget.

Strandskogen, Åse-Berit \& Rolf Strandskogen. 1980. Norsk grammatikk for utlendinger [Norwegian grammar for foreigners]. Oslo: Gyldendal.

Szmrecsanyi, Benedikt \& Bernd Kortmann 2009. Between simplification and complexification: Non-standard varieties of English around the world. In Sampson et al. (eds.), 64-79.

Thráinsson, Höskuldur. 1994. Icelandic. In König \& van der Auwera (eds.), 142-189.

Thráinsson, Höskuldur. 2007. The Syntax of Icelandic. Cambridge: Cambridge University Press.

Thráinsson, Höskuldur, Ásgrímur Angantýsson, Ásta Svavarsdóttir, Thórhallur Eythórsson \& Jóhannes G. Jónsson. 2007. The Icelandic (pilot) project in ScanDiaSyn. Nordlyd 34(1), $87-124$.

Torp, Arne. 2004. Nordiske språk i fortid og nåtid. In Iben Stampe Sletten (ed.), Nordens språk med røtter og føtter [Nordic languages with roots and feet], 19-74. København: Nordisk Ministerråd.

Torp, Arne \& Lars S. Vikør. 1994. Hovuddrag i norsk språkhistorie [Main features of Norwegian language history], 2nd edn. Oslo: Gyldendal.

Trudgill, Peter. 2000. On locating the boundary between language contact and dialect contact: Low German and continental Scandinavian. In Jahr (ed.), 71-85.

Trudgill, Peter. 2001. Contact and simplification: Historical baggage and directionality in linguistic change. Linguistic Typology 5(2/3), 371-374. 
Trudgill, Peter. 2011. Sociolinguistic Typology: Social Determinants of Linguistic Complexity. Oxford: Oxford University Press.

Van de Velde, Freek. 2012. PP extraction and extraposition in Functional Discourse Grammar. Language Sciences 34(4), 433-454.

Vikør, Lars S. 2001. The Nordic Languages: Their Status and Interrelations, 3rd edn. Oslo: Novus Press.

Vikør, Lars S. 2010. Language purism in the Nordic countries. International Journal of the Sociology of Language 2010(204), 9-30.

Vinje, Finn-Erik. 1978. Et språk i utvikling: Noen hovedlinjer i norsk språkhistorie fra reformasjonen til våre dager [A developing language: Some main directions in Norwegian language history from the Reformation until our time]. Oslo: Aschehoug.

Vinje, Finn-Erik. 2005. Norsk grammatikk: Det språklige byggverket [Norwegian grammar: The linguistic edifice]. Oslo: Kunnskapsforlaget.

Wray, Alison \& George W. Grace. 2007. The consequences of talking to strangers:

Evolutionary corollaries of socio-cultural influences on linguistic form. Lingua 117(3), 543-578. 